\title{
Establishment of the Deep Mine Microbial Observatory (DeMMO), South Dakota, USA, a Geochemically Stable Portal Into the Deep Subsurface
}

\author{
Magdalena R. Osburn ${ }^{1 *}$, Brittany Kruger ${ }^{2}$, Andrew L. Masterson ${ }^{1}$, Caitlin P. Casar ${ }^{1}$ and \\ Jan P. Amend ${ }^{3}$
}

${ }^{1}$ Department of Earth and Planetary Sciences, Northwestern University, Evanston, IL, United States, ${ }^{2}$ Division of Hydrologic Sciences, Desert Research Institute, Las Vegas, NV, United States, ${ }^{3}$ Departments of Earth Sciences and Biological

Sciences, University of Southern California, Los Angeles, CA, United States

\section{OPEN ACCESS}

Edited by:

Dawn Cardace,

University of Rhode Island,

United States

Reviewed by:

Brandy Marie Toner,

University of Minnesota Twin Cities,

United States

Andrew Elwood Madden,

University of Oklahoma, United States

${ }^{*}$ Correspondence:

Magdalena R. Osburn

maggie@northwestern.edu

Specialty section:

This article was submitted to

Biogeoscience,

a section of the journal

Frontiers in Earth Science

Received: 13 February 2019

Accepted: 16 July 2019

Published: 31 July 2019

Citation:

Osburn MR, Kruger B,

Masterson AL, Casar CP and Amend JP (2019) Establishment

of the Deep Mine Microbial

Observatory (DeMMO), South Dakota, USA, a Geochemically Stable

Portal Into the Deep Subsurface.

Front. Earth Sci. 7:196.

doi: 10.3389/feart.2019.00196
Identifying temporal trends in deep subsurface geomicrobiology is challenging as it requires both in-depth knowledge of in situ geochemistry and innovative sampling techniques. Subsurface microbial dynamics can only be understood in the context of accompanying geochemistry, and thus, it is imperative to first characterize available microbial habitats and their temporal evolution. Also, samples must be acquired in a clean and consistent manner to avoid artifacts stemming from surface microbes, atmospheric contamination, or external temporal variability. To facilitate these ends, we established the Deep Mine Microbial Observatory (DeMMO) in the Sanford Underground Research Facility (SURF), Lead, SD, USA to sample naturally draining fracture fluids at six spatially distributed sites from the shallowest $(800 \mathrm{ft})$ to the deepest accessible $(4,850 \mathrm{ft})$ depths. Here we report on the installation and subsequent two-year aqueous geochemical monitoring campaign of the DeMMO network. DeMMO fluids have distinct geochemical compositions showing differences with respect to depth, proximity to mine workings, and host rock geology. Most measurements were remarkably stable through the two-year sampling window, illustrating temporal stability of the water sources to each site, including over induced perturbations such as drilling. Interestingly, there was a lack of seasonality even at shallowest sites, indicating limited direct communication with modern meteoric waters. Patterns of fluid geochemistry are distinct between sites, and largely predictable based upon our understanding of the lithology and inorganic geochemistry of the host rocks. Thermodynamic calculations suggest that both inorganic and organic redox reactions can yield energy to, respectively, lithotrophic and heterotrophic microorganisms in this system, although the yields vary considerably by site. We conclude that each DeMMO site represents a unique window into the deep subsurface of SURF, accessing distinct fluid pockets, aqueous geochemistry, and dissolved gas geochemistry - providing stable conditions that facilitate long-term habitation of subsurface fractures and water pockets by distinct microbial communities.

Keywords: deep subsurface, mine geochemistry, Sanford Underground Research Facility, subsurface life, reaction energetics 


\section{INTRODUCTION}

The continental deep subsurface biosphere has garnered considerable research attention in the past three decades owing to its significance to water resources, carbon fluxes, and its identification as a reasonable astrobiological analog (Fredrickson and Onstott, 2001; Pedersen, 2001; Cavicchioli, 2002; Amend and Teske, 2005; Colwell and D'Hondt, 2013; Colman et al., 2017). A large number of studies focusing on sedimentary aquifers and igneous systems revealed diverse and active microbial populations that vary in abundance based on fluid type and host lithology (Murphy et al., 1992; Stevens and McKinley, 1995; Colwell and Lehman, 1997; Magot et al., 2000; Pedersen, 2001; Vetö et al., 2004; Flynn et al., 2008; Fry et al., 2009; Griebler and Lueders, 2009; Küsel et al., 2016; Simkus et al., 2016; Probst et al., 2016, 2018). For example, Stevens and McKinley (1995) proposed that the ecosystem of the Columbia river flood basalt is supported solely by chemolithoautotrophic primary producers, although this was subsequently vigorously debated (Nealson et al., 2005). The arguments for surface-independent subsurface ecosystems are complicated by and challenged by considerable sample-to-sample variability in cell density and input of fossil and surficial organic carbon.

Deep igneous and metamorphic terranes have emerged as arguably the most relevant to astrobiology. This is due to their long-term isolation from surficial water and organic carbon inputs and the possibility of life existing, and even thriving, on chemical disequilibria produced through water-rock interactions alone. In the most extreme examples, fluids may be have been isolated for billions of years, even preserving signatures of early Earth (Holland et al., 2013; Li et al., 2016). Geochemical and geomicrobiological surveys into the Fendoscandian shield revealed depth gradients of microbial populations, presumably taking advantage of redox disequilibria at different horizons (Nyyssonen et al., 2013; Kietavainen et al., 2017). Sites in the South African shield revealed remarkably low diversity ecosystems dominated by only the metabolically-flexible organism Desulforudis audaxviator (Chivian et al., 2008; Magnabosco et al., 2015). Recent extrapolation reveals similar microbial ecotones in deep continental systems globally (Purkamo et al., 2016; Momper et al., 2017a).

As the state of the art has evolved past samples of opportunity, an effort is being made to set up long-term monitoring sites to study deep subsurface microbiology. Established sites include the Äspö Hard Rock Laboratory (Sweden); ONKALO (Finland); Mont Terri Rock Laboratory (Switzerland); Sudbury Neutrino Observatory Laboratory and Kidd Creek Mine (Canada); Soudan Underground laboratory, Permafrost Tunnel Research Laboratory, and Coast Range Ophiolite Microbial Observatory (United States); and the Boulby Underground Laboratory (United Kingdom) (Pedersen, 1996; Stroes-Gascoyne et al., 2007; Cardace et al., 2013; Pedersen et al., 2014). These observatories cover a large range of host lithology, water age, and interaction with surficial inputs and outputs. The purpose of this communication is to expand this list to include the deep metamorphic aquifers of South Dakota, United States, and to provide geochemical context within which to investigate the resident microbial communities and their metabolic activities.

\section{THE SANFORD UNDERGROUND RESEARCH FACILITY (SURF)}

The Sanford Underground Research Facility (SURF) is hosted in the former Homestake Gold Mine in Lead, South Dakota, United States. The Homestake Mine was active between 1876 and 2001, reaching a depth of over $8100 \mathrm{ft}(2469 \mathrm{~m})$ below land surface, and producing 1,101 metric tons of gold (Caddey, 1991; Mitchell, 2009; Heise, 2015). The site was donated to the state of South Dakota in 2006 and was ultimately developed into a dedicated science facility. The core of SURF infrastructure is on the $4850 \mathrm{ft}$ (1478 m) level (below surface) including several large particle physics detectors (Heise, 2015). Active pumping maintains water levels well below the $5000 \mathrm{ft}$ levels, although the facility was flooded to the $4100 \mathrm{ft}$ level between the end of mining and the establishment of new science facilities. Note that the level depths are given in feet in accordance with the facility naming scheme.

SURF is hosted in heavily deformed, iron-rich, Paleoproterozoic metasediments with a complex geological history. Lithological units accessed within the mine workings in ascending stratigraphic order are the Poorman Formation, the Homestake Formation, and the Ellison Formation that collectively document voluminous oceanic volcanism and subsequent infilling of the marine basin. The Poorman Formation contains a distinct basal metaigneous member called the Yates Unit followed by up to $1000 \mathrm{~m}$ of metasedimentary deposits of mostly well banded sericite-biotite phyllites, carbonate-bearing phyllites, and graphitic phyllites. The orebearing Homestake Formation is a thin metamorphosed carbonate-type iron formation with abundant sulfides and mineralogy dependent on metamorphic grade. The overlying Ellison Formation is similar to the Poorman Formation comprising mostly sericite-biotite schists, quartzites, and tuffaceous igneous components with a more continental character (Caddey, 1991). The depositional age of these metasediments is constrained to less than $1.97 \mathrm{Ga}$ by a zircon age from a tuff in the Ellison Formation (Caddey, 1991). This sequence is crosscut by tertiary-aged rhyolitic and phonolitic dikes and sills. Ore mineralization is concentrated primarily within the Homestake Formation and occurred largely contemporaneously with regional metamorphism and striking ductile deformation circa $1.84 \mathrm{Ga}$, potentially associated with emplacement of large granitic bodies (Caddey, 1991). While the mine infrastructure exists to facilitate retrieval of gold ore, only $3 \%$ by volume of host rocks are ore bearing (Caddey, 1991), leaving substantial swaths of undisturbed habitat for subsurface microbes. Both the Precambrian age and iron-rich character of the rocks at SURF affect the chemistry of the borehole fluids, contributing to the diverse array of microbial inhabitants (Osburn et al., 2014).

Previous geochemical and geomicrobiological work at SURF has focused on the ore formation and emplacement 
(Caddey, 1991; Morelli et al., 2010; Steadman and Large, 2016), hydrology (Murdoch et al., 2011; Kennedy et al., 2015), and geomicrobiology of mine biofilms and soils largely in the context of bioprospecting (Rastogi et al., 2009, 2010, 2013; Waddell et al., 2010). In 2013 the NASA Astrobiology Institute Team Life Underground began work at SURF, characterizing geochemistry, microbiology, and redox reaction energetics at key sites with an eye toward habitability (Osburn et al., 2014). This was followed by detailed DNA sequencing of microbes contained within rock and fluid samples identifying key lithophilic taxa (Momper et al., 2017b) and a metagenomic investigation of two sites resulting in large scale genome assembly and metabolic assessment (Momper et al., 2017a). These studies collectively reveal distinct populations of subsurface microbes, many from wholly uncultivated lineages, with interesting metabolic strategies tailored to subsurface, rock-associated habitats.

Our initial work at SURF revealed the need for dedicated sampling infrastructure to effectively monitor flowing boreholes through time. While samples of opportunity provided a glimpse of interesting microbial ecosystems, replicability of these samples were limited and contamination of fracture samples with mine atmosphere and microbial inhabitants was a constant threat. To alleviate these problems, we sought to establish an observatory of sites through the mine where access could be controlled, fluids could be collected cleanly and consistently, and long-term experimental apparatus could be deployed for the long timescales over which many subsurface organisms grow. Monitoring of each site for geochemical and microbiological parameters before and after modification was a key goal. Here we report on a two-year time series of aqueous and gas geochemical monitoring. The microbial ecology of these sites and temporal dynamics therein is beyond the scope of this manuscript.

\section{MATERIALS AND METHODS}

\section{Borehole Modification}

Many hundreds of exploratory boreholes were drilled over the 125 years of mining operations and more subsequently as underground science facilities were built. Of these, six diamond drill holes were chosen for the DeMMO network based on host lithology, fluid flow rate, accessibility by monitoring teams, and fluid chemistry. Each of the six sites featured unique challenges and was modified as deemed possible and safe by SURF personnel. Two locations (D1 and D2) were inaccessible for drilling and were instead modified with hand tools and fitted with simple drain packers to restrict the inflow of mine atmosphere and channelize outflow. Three holes (D3, D4, and D5) were drilled with a diamond bit and fitted with custom designed expandable packers (Figure 1). Drilling was conducted in May 2016 by SURF personnel using legacy jackleg drilling methods, in which historic $2^{\prime \prime}$ exploration holes (previously filled with concrete to control water outflow) were re-drilled with a $3^{\prime \prime}$ diameter reaming bit to a depth of $5-6^{\prime}$. As such, foreign material was removed, unimpeded water outflow was restored, and fresh, smooth, rock surface was exposed to ensure appropriate contact with expandable packer surfaces. We will subsequently refer to this as borehole outlet modification. The last site (D6) was left in its original form with a steel manifold as it was not safe to modify.

Packers were custom built from acetal holopolymer material (Delrin) following a commercially available design (Margo Packer). It was deemed essential to avoid metal components in the packers, because many metals can influence microbially relevant aqueous redox chemistry. Stock Delrin components (McMaster Carr) were machined as needed (Princeton University, Geosciences Machine Shop) to create the nested-component design illustrated in Figure 1. In short, a hollow inner tube allows for the continuous outflow of fracture fluids accessed by the borehole, while an outer, mobile sleeve serves to compress four polyurethane bushings (Shore hardness $=60 \mathrm{~A}$, custom poured by PSI Urethanes, Inc.), thereby creating a seal with the borehole wall to eliminate communication with the local mine atmosphere. To control and sample outflowing fluid, a custom 5-port sampling manifold (Delrin) outfitted with polypropylene ball valves (Parker, US Plastic Corp.) was attached to each installed packer. Once installed, the packers and manifolds were not removed. Each DeMMO site was sampled upon each visit to SURF, including before, during, and after hole modification, creating a two-year time series from December 2015 to November 2017.

\section{Field Methods}

Site visits were conducted within a 4-day window in accordance with underground access schedules and necessary transit times. At each site temperature, $\mathrm{pH}$, conductivity, total dissolved solids (TDS), and oxidation reduction potential (ORP) were measured with a portable Myron Ultrameter II. For D6 which needed to be opened, fluids were allowed to run for 2-5 min to stabilize prior to measurement. Samples were collected for major anions and cations, dissolved organic carbon (DOC), dissolved inorganic carbon (DIC), and dissolved gas geochemistry. All samples collected on site were preserved as appropriate (cool, frozen, or on dry ice) before transport back to the laboratory for analysis.

Redox sensitive ions were measured on site using a portable Hach DR1900 Spectrophotometer and associated reagent kits as described below. Hydrogen sulfide was measured by the methylene blue colorimetric method (Hach 8131). Ferrous iron concentrations were measured using the 1,10 phenanthroline method (Hach method 8146). Nitrate concentrations were measured using the NitraVer5 cadmium reduction method (Hach method 8039) and ammonia concentrations were measured using the Salicylate colorimetric method (Hach method 8155). Dissolved oxygen (DO) concentrations were also measured with low and high range ampules (Indigo Carmine Method, Hach methods 8316 and 8166, respectively), but poor reproducibility of these data on duplicate samples calls into questions its accuracy, and we report only averages. All kitbased measurements were conducted according to manufacturer instructions, and dilutions were performed with deionized water as necessary.

\section{Aqueous Geochemistry}

Filtrate $(<0.22 \mu \mathrm{m})$ was collected in lab-supplied plastic bottles with nitric acid preservative or new plastic tubes for ICP-MS 


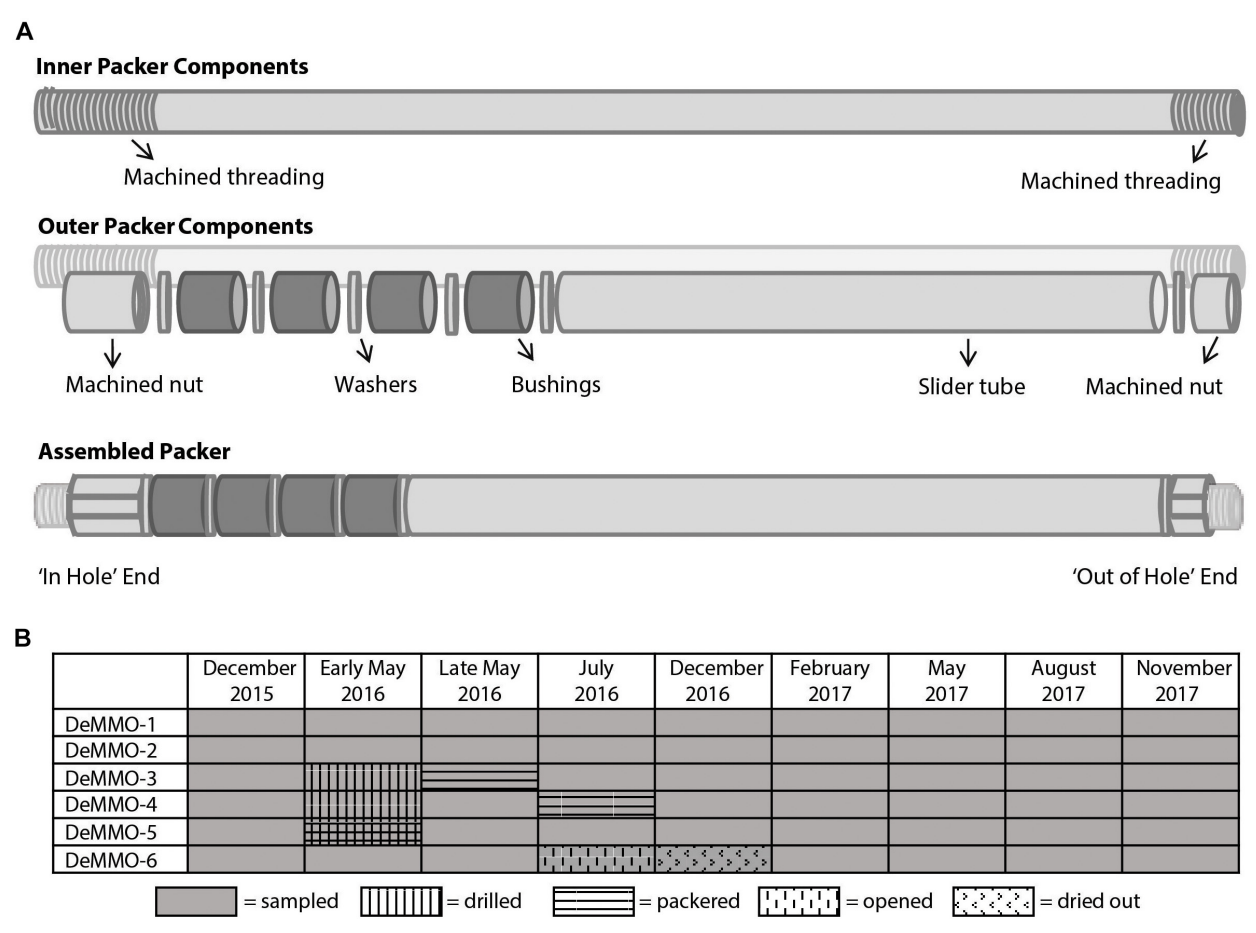

FIGURE 1 | (A) Packer design used to modify DeMMO 3, 4, and 5 illustrating the inner components, outer components, and assembled design. Dark gray bushings are expanded to create the seal with the borehole. (B) Timeline of sampling and hole modification.

(EPA method M200.7) and IC (EPA Method M300.0) analysis of major dissolved cations and anions, respectively, by ACZ laboratories. For IC methods, $\mathrm{Br}^{-}, \mathrm{Cl}^{-}, \mathrm{F}^{-}$, and sulfate were analyzed and had minimum detectable levels of $0.25,2,0.25$, and $2 \mathrm{mg} / \mathrm{L}$, respectively. For ICP methods we analyzed (minimum detectable levels in ppm), Al (0.03), Ar (0.04), Ba (0.02), B (0.01), Cd (0.005), Ca (0.1), Cr (0.01), Cu (0.01), Fe (0.02), $\mathrm{Pb}$ (0.03), Li (0.008), Mg (0.2), Mn (0.005), Mo (0.02), Ni (0.008), Se (0.05), Si (0.1), Ag (0.01), Na (0.02), and Zn (0.01). Filtrate samples for DOC concentrations were collected in acidwashed ( $4 \mathrm{~h}$ in $10 \% \mathrm{HCl}$, DI rinsed) and combusted $(4.5 \mathrm{~h}$ at $450^{\circ} \mathrm{C}$ ) amber glass VOC vials with PTFE lined acid-washed caps, brought to $\mathrm{pH} \sim 2$ with $6 \mathrm{~N} \mathrm{HCl}$, and stored at $4^{\circ} \mathrm{C}$ until measured by Anatek Labs, using method SM 5310B (nonpurgeable organic carbon).

Samples for DIC and its respective $\delta^{13} \mathrm{C}$ value $\left(\delta^{13} \mathrm{C}_{\mathrm{DIC}}\right)$ were taken in ashed, helium-flushed, and evacuated Exetainers ${ }^{\circledR}$ and measured in house at the Northwestern Stable Isotope Facility via continuous flow on a ThermoFisher GasBench II, coupled to a Delta V Plus isotope ratio mass-spectrometer (CF-IRMS). Approximately $1 \mathrm{~mL}$ aliquots of each sample were syringe-injected into acidified $\left(103 \% \mathrm{H}_{3} \mathrm{PO}_{4}\right)$ and helium-purged Exetainer ${ }^{\circledR}$ vials. The samples were then re-weighed to determine exact quantity, placed in the thermostated block of the GasBench II, and carbon dioxide allowed to evolve at $25^{\circ} \mathrm{C}$ for a minimum of $12 \mathrm{~h}$. Sample carbon dioxide is sub-sampled by a PAL autosampler and $\delta^{13} \mathrm{C}$ values determined by averaging 8 separate injections of $\sim 100 \mu \mathrm{L}$ each. The isotopic composition, $\delta^{13} \mathrm{C}_{\mathrm{DIC}}$, is corrected using the periodic sampling of carbon dioxide from the $\mathrm{H}_{3} \mathrm{PO}_{4}$-acidified $\mathrm{CaCO}_{3}$ standards NBS18 and NBS19 (respectively, $\delta^{13} \mathrm{C}_{\mathrm{VPDB}}=-5.014 \% 0, \equiv 1.95 \%$ ), and samples reported on the VPDB scale. Estimated precision (1 standard deviation) on total Dissolved Inorganic Carbon concentration ([DIC]) and $\delta^{13} \mathrm{C}_{\mathrm{DIC}}$ are $\pm 40 \mu \mathrm{M}$ and $\pm 0.1 \%$, respectively.

\section{Dissolved Gas Geochemistry}

Dissolved gas samples were collected using the bubble stripping method of Chapelle et al. (2002) modified by Alter and Steiof (2005). In short, borehole fluid was directed through a glass gas sampling bulb, a $10 \mathrm{~mL}$ bubble of pure Ar was introduced into the chamber and the system was allowed to reach equilibrium while monitoring flow rate and temperature. The sample bubble was then removed and stored in an Ar-flushed and evacuated $10 \mathrm{~mL}$ Serum bottle previously capped with solid butyl rubber stoppers and crimped tin seals. Gas samples were analyzed on a Shimadzu GC-2014ATF Headspace GC equipped with Haysep 80/100 (5 m) and MS-5A 60/80 (2.5 m) molecular sieve columns and TCD and FID detectors. Dissolved gas concentrations were calculated from equilibrated gases based on solubility constants of each gas at the collection temperature and pressure as well as in reference to analytical standards.

\section{RESULTS}

\section{Description of DeMMO}

The selection of sites for the DeMMO network was undertaken with consideration of long-term accessibility, adequate fluid flow, 
host lithology, and depth. The six chosen sites span a range of depths (800-4,850 ft), flow conditions, and host lithologies (Table 1 and Figures 2A,B).

Two sites (D1, D2) are on the $800 \mathrm{ft}$ level (Figure 2A). While, on the same horizontal plane, these boreholes intersect very different areas of mine geology and have different histories. D1 (historical name 10-1) was the tenth diamond borehole drilled at the Homestake Mine circa 1910. It is $1400 \mathrm{ft}$ long (427 m) drilled eastward, away from any documented mining excavations. The bit drifted upward during drilling, terminating near Whitewood Creek. This borehole starts in Ellison Formation lithologies of chlorite-mica-garnet schists and phyllites, transitioning into unidentified metaigneous amphibolites, and subsequently tertiary intrusive rhyolites. The borehole log notes intersecting a water course at the hole terminus, which may be the current source of abundant flow (averages $2.5 \mathrm{~L} / \mathrm{min}$ ). The proximity of this water source to the surface could leave open the possibility of seasonal influence at this site, which we will evaluate below. In contrast, D2 (historical name \#19223) intersects a complex region of folded Ellison, Homestake, and Poorman formations in an area with extensive sulfide mineralization and mined stopes. The hole begins in well-banded tan, brown, and gray phyllites of the Ellison Formation, followed by yellow-banded and mineral-rich Homestake Formation phyllites, gray - green and brown Poorman Formation phyllites, and rhyolitic to porphyritic intrusive igneous rocks. Significant minerals noted on the bore hole logs are graphite, sericite, cummingtonite, chlorite, chert, siderite, carbonate, biotite, quartz, fluorite, pyrrhotite, pyrite, and arsenopyrite. Fluids from both D1 and D2 are fresh, with conductivities $<1 \mathrm{mS}$ and relatively cool, with average temperatures of 10.3 and $12.5^{\circ} \mathrm{C}$, respectively.

D3 (historical name \#24790) is uniquely situated in a remote region of the $2000 \mathrm{ft}$ level (Figure 2A) and was drilled in 1999 during the final phase of mining and exploration of the working Homestake Mine. This is a relatively short borehole $(398 \mathrm{ft} ; 121 \mathrm{~m})$ drilled at a steep upward angle. Intersected lithologies include gray to tan banded sericite, graphite, chert-bearing phyllites (Poorman Formation); gray green and white massive to banded Homestake Formation with biotite, sericite, chlorite, chert, vein quartz, graphite, siderite, pyrite, pyrrhotite, and arsenopyrite, and poorly banded sericite, graphite, and biotite phyllites (Ellison Formation). These rocks were not visibly intruded by tertiary volcanism. Currently the hole has strong flow $(\sim 1.5 \mathrm{~L} / \mathrm{min})$ and features periodic eruptions of gas bubbles and particulate iron oxides. Measured ORP is consistently high (average $-28 \mathrm{mV}$ ) but dissolved oxygen is undetectable. The fluids are consistently brackish with an average conductivity of $3 \mathrm{mS}$.

D4 (historical name \#24228) is on the $4100 \mathrm{ft}$ level very near, but not intersecting the Ross Shaft. This hole is unusual in that it was drilled at a downward angle (Figure 2A) that, importantly for the geochemistry and habitability, limits contamination with oxygen from the mine atmosphere. The drilling log is relatively simple, spanning $941 \mathrm{ft}(287 \mathrm{~m})$ and featuring primarily Poorman Formation banded graphite-biotite phyllites that variably include carbonate, sericite, chlorite, and garnets. Pyrrhotite and pyrite mineralization is noted throughout the core.

D5 (historical name \#11938) and D6 (historical name DUSEL B) are both on the $4850 \mathrm{ft}$ level, but as with D1 and D2, intersect very different rocks and feature different fluid chemistry. D5 (hole \#11938) was drilled in 1978 during excavation of the 17-ledge mining area (see Figure 2A). It is $943 \mathrm{ft}(287 \mathrm{~m})$ long and intersects a wide range of lithologies. Notably this hole is in a drift with very significant modern fluid flow through both old boreholes and other fractures, commonly featuring abundant growth of white microbial biofilms and streamers. The trajectories of D4 and D5 trend toward a similar source area, between areas of significant excavation. We will evaluate the potential for similar hydrological source areas of D4 and D5 below. D5, however, intersects a much more diverse range of host lithologies, including the Poorman, Homestake, and Ellison formations as well as transitional facies between those units.

D6 was drilled in 2009 in preparation for construction of the proposed Deep Underground Science and Engineering Laboratory (DUSEL) facilities. This hole, along with its sister holes, in the same drift (DUSEL C, D, J, and 3A, not sampled), intersect the Yates Unit metabasalts with periodic rhyolitic tertiary dikes. D6 is $603 \mathrm{ft}(184 \mathrm{~m})$ long and was intentionally drilled in a direction of very limited mining influence where very significant fluid pressures were encountered. In contrast to the other fluids, those from D6 are much more saline, up to $\sim 8 \mathrm{mS}$. Logistical concerns prevented re-packering of this hole to a continuous flow system similar to the other DeMMO sites, however, we did install continuous flow experiments at this site in July 2016, changing this from a closed system to an open system. After 6 months of continuous

TABLE 1 | Site characteristics of DeMMO and surrounding rocks.

\begin{tabular}{|c|c|c|c|c|c|c|c|}
\hline DeMMO site & Depth (ft) & Depth (m) & Host lithology* & Temp. $\left({ }^{\circ} \mathbf{C}\right)^{+}$ & Cond. $(\mu \mathrm{S})$ & ORP (mV) & TDS (ppm) \\
\hline D1 & 800 & 244 & $\mathrm{PF}, \mathrm{YU}, \mathrm{tP}-\mathrm{Y}, \mathrm{Ti}$ & $10.3 \pm 0.3$ & $966 \pm 34$ & $-90 \pm 31$ & $694 \pm 26$ \\
\hline D2 & 800 & 244 & $\mathrm{EF}, \mathrm{HF}, \mathrm{PF}, \mathrm{Ti}$ & $12.5 \pm 0.1$ & $619 \pm 8$ & $-125 \pm 36$ & $438 \pm 6$ \\
\hline D3 & 2000 & 610 & $\mathrm{PF}, \mathrm{tP}-\mathrm{H}, \mathrm{HF}, \mathrm{EF}$ & $16.2 \pm 0.2$ & $3036 \pm 15$ & $-28 \pm 35$ & $2312 \pm 13$ \\
\hline D4 & 4100 & 1250 & $\mathrm{PF}, \mathrm{tP}-\mathrm{H}$ & $22.6 \pm 0.3$ & $1781 \pm 42$ & $-217 \pm 46$ & $1302 \pm 34$ \\
\hline D5 & 4850 & 1478 & $\mathrm{PF}, \mathrm{tP}-\mathrm{H}, \mathrm{HF}, \mathrm{EF}$ & $31.8 \pm 0.6$ & $1545 \pm 10$ & $-213 \pm 59$ & $1112 \pm 8$ \\
\hline D6 & 4850 & 1478 & YF, Ti & $21.6 \pm 1.2$ & $7925 \pm 53$ & $-244 \pm 68$ & $6602 \pm 50$ \\
\hline
\end{tabular}

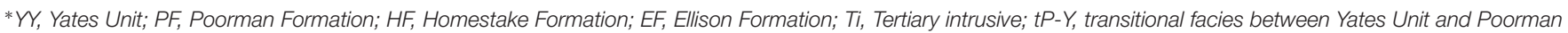

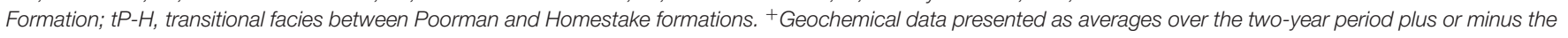
standard deviation of those measurements. 

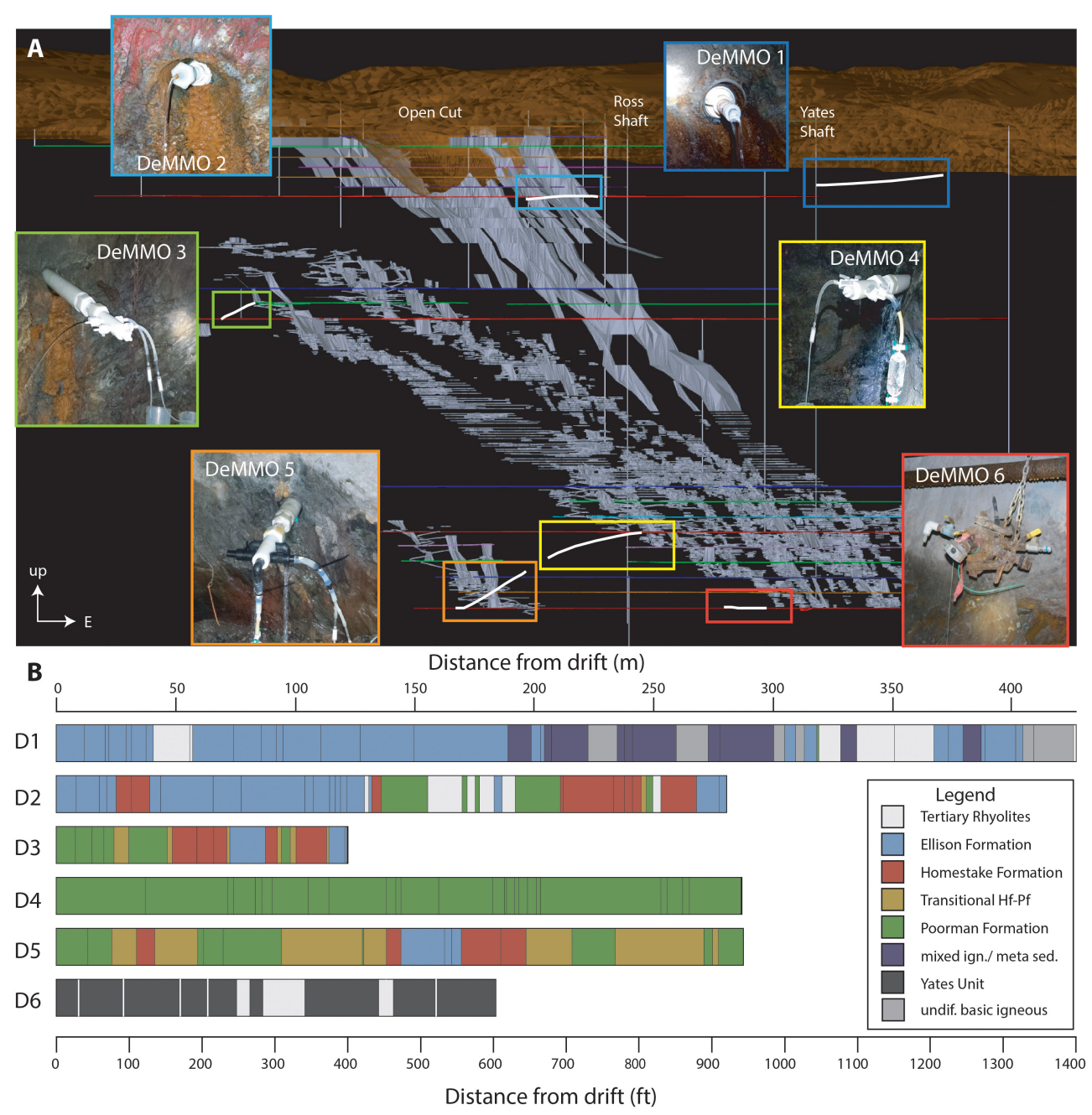

FIGURE 2 | Overview of SURF superstructure and borehole placement, trajectories, and intersecting lithologies. (A) A 3D georeferenced map of SURF and picture of each site. View is looking from south to north (map made by Kathy Hart using Vulcan Software printed with permission from SURF). Mined stopes shown in gray, borehole trajectories in white, mining levels in colored horizontal lines, and shafts in vertical gray lines. (B) Lithological units in boreholes from origin (0) to terminus compiled from each borehole log report.

flow, the hole ran dry and was closed and is now only opened for sampling trips and by safety personnel to mitigate pressure buildup.

\section{Water Isotopes}

The isotopic compositions of hydrogen and oxygen in water are often used as a first line of evidence regarding the original source of groundwater (Gat, 1996; Criss, 1999). We employ this classical technique as a means of both assessing the original source of fluids and also for identification of seasonal variability. Figure 3A shows isotopic data for DeMMO fluids plotted with the meteoric water line (MWL) and Online Isotopes in Precipitation Calculator (OIPC) estimates for month local precipitation (Welker, 2000; Bowen and Revenaugh, 2003; Bowen et al., 2005; Bowen, 2018). Strong seasonality in the climate above SURF produces distinct trends in the water isotope composition of precipitation driven primarily by temperature and vapor sources. The most depleted values occur in December, January, and February produced by cold temperatures and significant snowfall, whereas the most enriched values occur in August. The average isotope composition of annual precipitation approximates that which occurs between September and October of a given year.

\section{Conservative Aqueous Geochemistry}

Ternary diagrams of aqueous geochemistry at the six sites (Figure 4) reveal a broad range of cationic compositions, a fairly narrow range of anionic compositions, and extremely consistent behavior of individual sites through time. In fact, individual sites are so consistent that most data points plot within analytical error of each other, and thus long-term variability in this chemistry will not be discussed.

The cation data (Figure 4A) show separation by station depth, with considerable differences between the deepest 

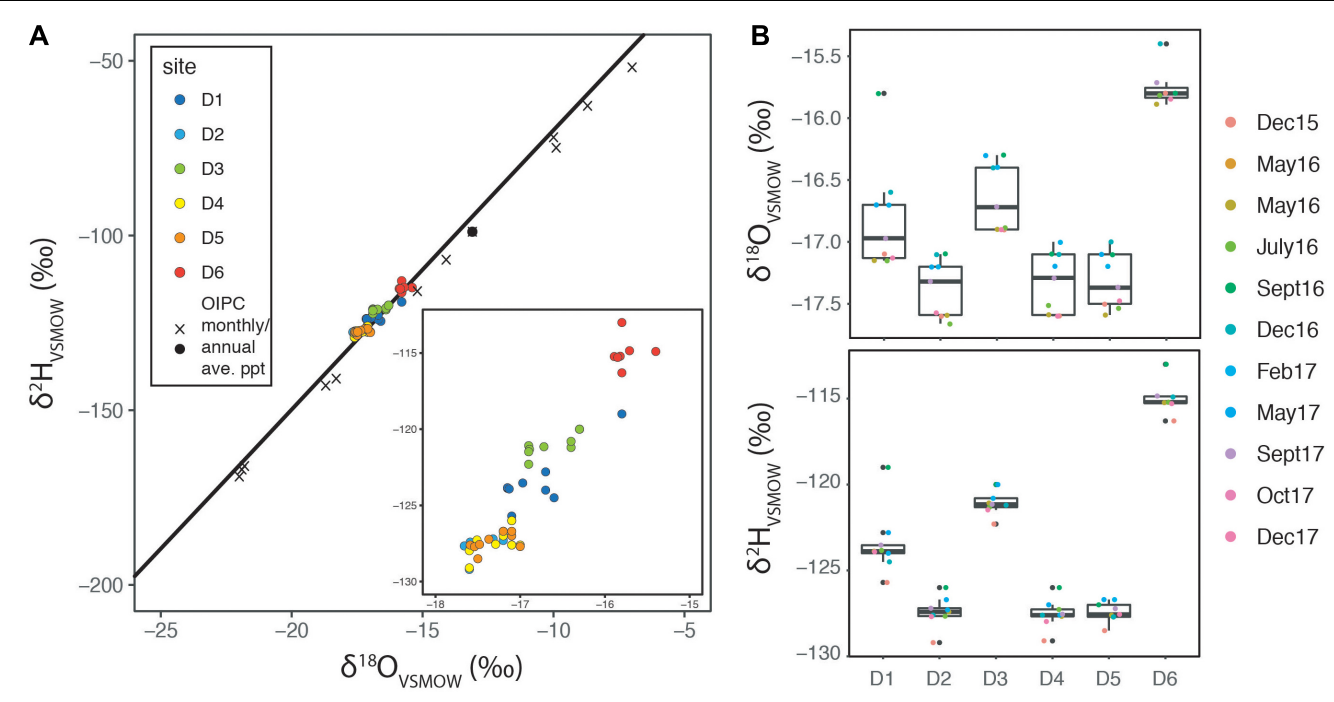

FIGURE 3 | Water isotopes of DeMMO sites and overlying land (A) Plot of water isotopes for DeMMO sites plotted on the meteoric water line and OIPC estimates of monthly average and annual precipitation. Inset expands borehole data range. (B) Box plots showing variability with time in both $\delta^{18} \mathrm{O}$ and $\delta^{2} \mathrm{H}$ where points are colored by the sampling date.

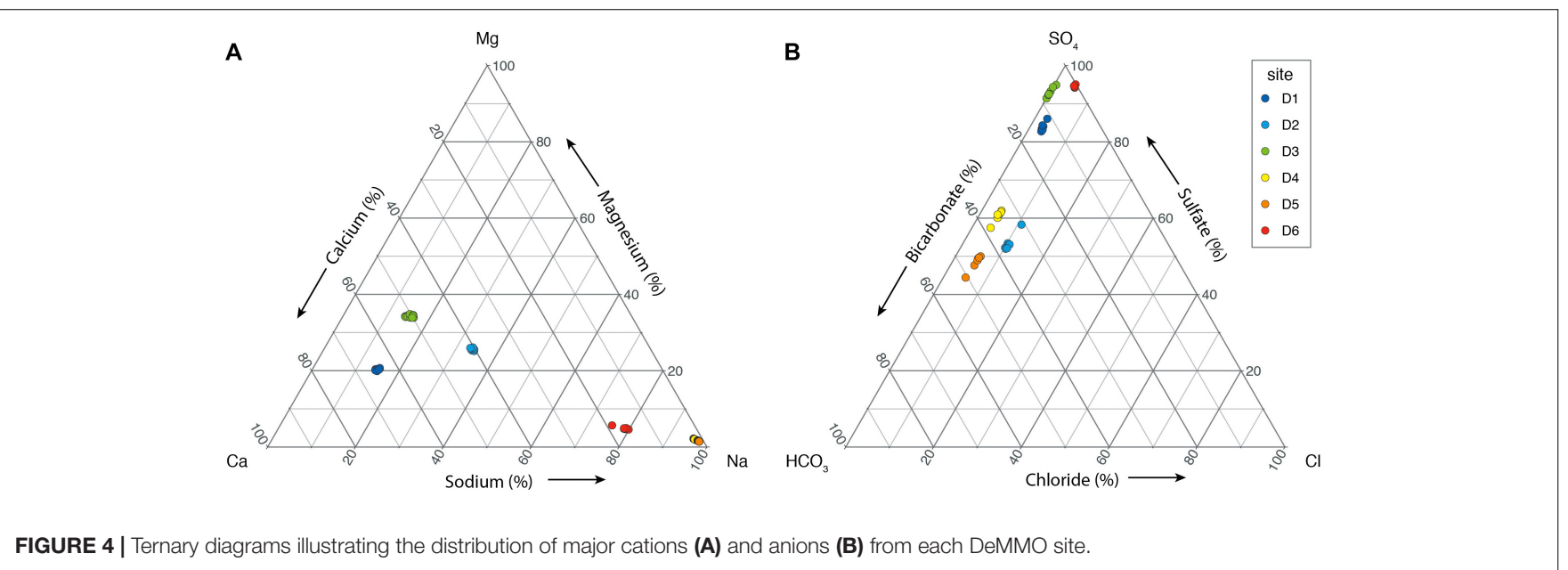

three, and the shallowest three samples. Deep samples (D4-D6) are sodium-type waters, whereas shallow samples (D1-D3) contain significantly more calcium and to a lesser extent magnesium. The anion data (Figure 4B) show that D1, D3, and D6 are sulfate-type waters, whereas D2, D4, and D5 have approximately even concentrations of sulfate and bicarbonate. Chloride is a minor component in these waters.

Each site is characterized by a distinct aqueous geochemistry. D4 and D5 are the most similar, with indistinguishable cation and chloride levels, and minor variations along the $\mathrm{SO}_{4}-\mathrm{HCO}_{3}$ axis. $\mathrm{D} 1$ and $\mathrm{D} 3$ are also similar, but with distinct calcium-magnesium and $\mathrm{SO}_{4}-\mathrm{HCO}_{3}$ signatures. D2 is consistently intermediate to the other samples and uniquely contains appreciable (although still low) levels of $\mathrm{Cl}^{-}$. We hypothesize that these distinct chemistries result from different lithological composition present in the water source area for each site and also residence time of water through those rocks and will evaluate this hypothesis below.

\section{Redox Sensitive Geochemistry}

Measurements of redox sensitive ions are relatively rare in geochemical datasets owing, in part, to the difficulty of performing these measurements in the field. However, these are also the ions most likely to be cycled by microbes, and are thus their quantification is critical to characterizing lithotrophic habitability. Using portable meters, we monitored ferrous iron, nitrate, ammonium, and sulfide, as well as ORP at all time points after the December 2015 trip. The concentrations of all measured redox sensitive ions and ORP are temporally quite stable, despite potential notable uncertainties in the colorimetry techniques.

As with conservative ions, redox sensitive ions produce distinct fingerprints for each site. We observe broad covariation between nitrate, ammonium, and sulfide concentrations, 
particularly at D4 and D5, which have consistently high ammonium and sulfide values, and correspondingly negative ORPs. Ferrous iron is elevated in D1, D3, and D6, presumably from interactions with mafic volcanic rocks and/or steel in previously mined cavities. Note in Figure 5 that ferrous iron levels at D6 increase with time; a similar range $(0.7-3.0 \mathrm{mg} / \mathrm{L})$ was previously observed in Osburn et al. (2014). In the dataset described here, the low values correspond to times when the steel manifold was closed, and the high values to times when fluid was continually flowing. This is opposite to what would be predicted if the manifold itself was the source of ferrous iron.

\section{Dissolved Gases}

Dissolved gas concentrations exhibit significant variability through time and between sites (Figure 6). Carbon dioxide is the most stable and distinct measurement between sites, with decreasing average concentrations observed with depth for D1, D2, D4, D5, and D6. The outlier is D3, with consistently twofold (or more) higher concentrations. Field observations of the fluid streams at D3 confirm visible bubbles in the fluid stream from this site, which, based on these data, are likely mostly carbon dioxide. Concentrations of carbon monoxide and hydrogen are low $(<1 \mathrm{nM})$ and exhibit no significant trends. Levels of helium, methane, and ethane covary, with elevated concentrations at D4, D6, and to a lesser extent D5. The methane/ethane ratios average 24, 76, 192 for D4, D5, and D6, respectively. Dissolved oxygen was measured colorimetrically and are of variable quality, with many analyses strongly affected by rapid oxidation post-sampling. The dissolved oxygen measurements should therefore be taken as maximum values, and we do not plot them with
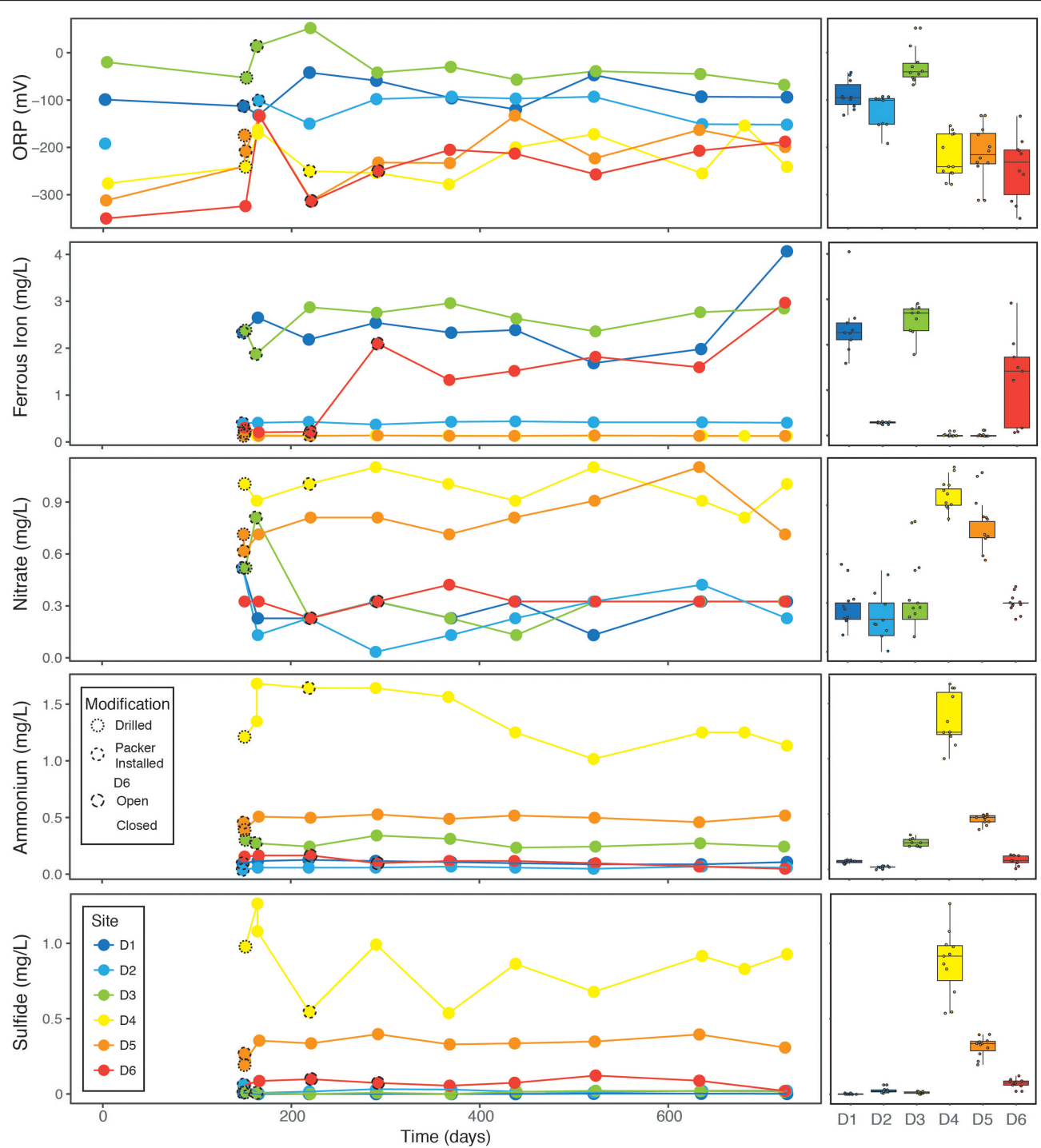

FIGURE 5 | Combined line plots and box plots of redox sensitive geochemical measurements showing change with time and aggregated site averages, interquartile ranges, and data points. 

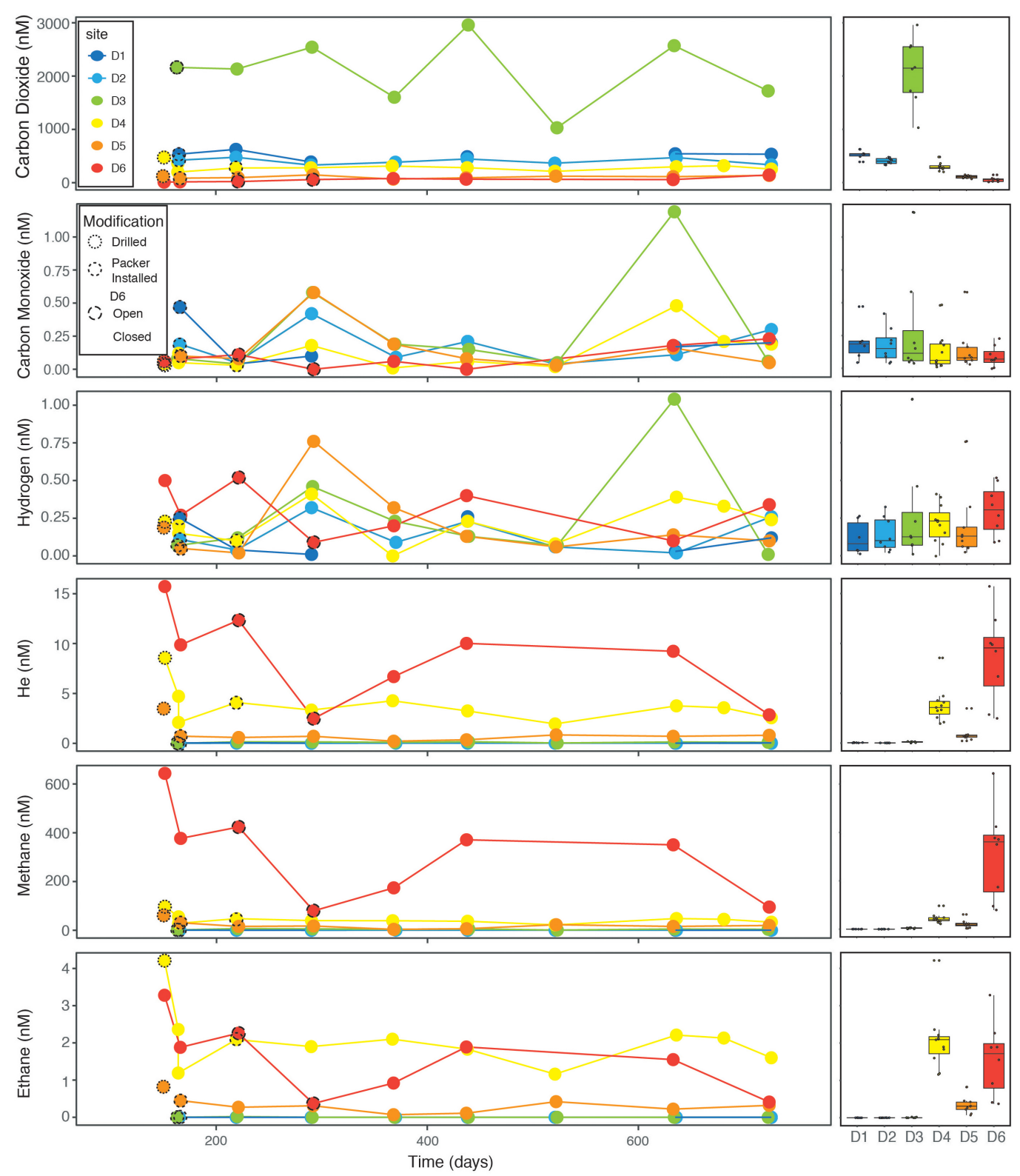

FIGURE 6 | Dissolved gas concentrations by site through time (left) and aggregate box plots illustrating average, interquartile range, and data points (right).

time; instead, we rely on ORP to record oxidation states of these fluids.

\section{Carbon Chemistry ([DIC], $\left.\delta^{13} \mathrm{C}_{\mathrm{DIC}}, \mathrm{DOC}\right)$}

Concentrations of DIC and DOC vary considerably among the DeMMO sites, but they are temporally quite stable (Figure 7). DIC levels are highest in D4, D5, and D3 (generally $>10 \mathrm{mM}$ ), and much lower in D1, D2, and D6 $(<5 \mathrm{mM})$. These differences do not appear to correlate with $\mathrm{pH}$ or dissolved carbon dioxide, suggesting distinct sources rather than equilibrium partitioning. The isotopic differences in DIC (Figure 7) follow a similar site pattern, with more enriched values in D3, D4, and D5 and slightly more depleted values in the others, particularly D6. Of note is the unusual trend at D3, where the earliest value is very enriched, but then decreases steadily to $-8 \%$.

It can be seen in Figure 7 that DOC concentrations vary broadly along a depth gradient, with additional variation in D6 through known perturbations. The shallowest sites, D1 and D2, have relatively high DOC levels $(\sim 0.035 \mathrm{mM})$, but this is still quite low compared to surface oligotrophic fluids, which typically range closer to $1 \mathrm{mM}$ (Leenheer et al., 1974). DOC concentrations are lower in D3, D4, and D5, with a slight depth relationship. D6 has extremely variable DOC concentrations ranging from near those of the shallow sites to the lowest observed values $(0.01 \mathrm{mM})$. The significant drop in concentration at the beginning corresponds to when the systems transitioned 

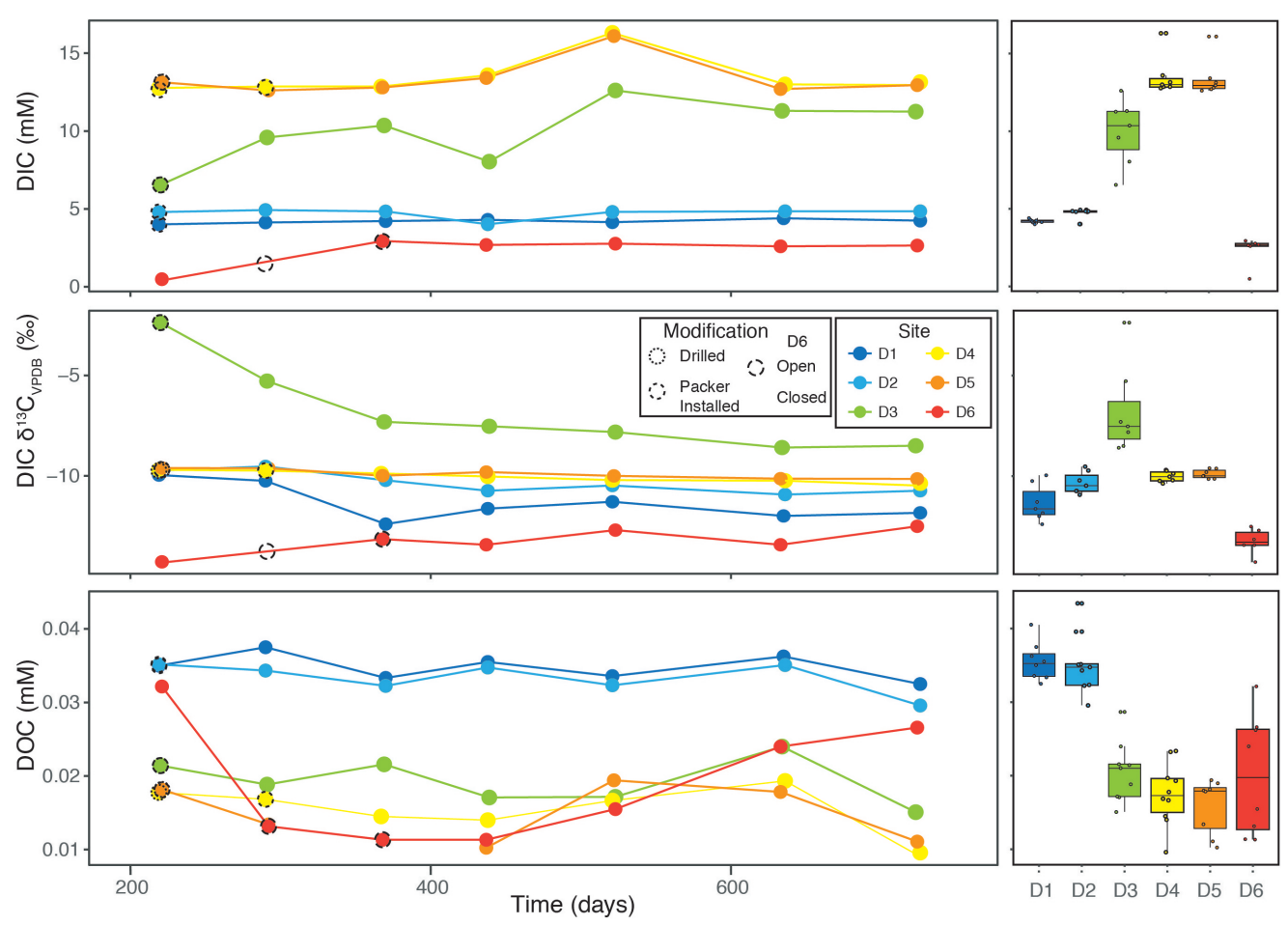

FIGURE $7 \mid$ Box and line plots of DIC, $\delta^{13} \mathrm{C}_{\mathrm{DIC}}$, and DOC.

from a closed manifold to an open flowing system. The hole at D6 eventually drained and was subsequently left sealed except to sample. The DOC concentration there appears to be rebounding after this change in protocol.

\section{DISCUSSION}

\section{Relationship Between Different Sites Determining Water Source}

Taken together, the suite of geochemical data at SURF can point to relationships between sampling sites, the relative age of the fluids, and likely fluid flow paths. Our water isotope data (Figure 3) suggest a relatively unaltered meteoric signal with limited hydrothermal input for all DeMMO sites. While there is variability with time at each sample location $\left(1 \%\right.$ in $\delta^{18} \mathrm{O}$ and $\sim 5 \%$ in $\delta^{2} \mathrm{H}$ ), there does not appear to be seasonal variation at any site. For instance, samples from D1 taken in December 2015, May 2016, and September 2016 are all similar (and depleted) despite the fact that corresponding relative monthly precipitation isotope values span a much larger range. This suggests that even at the site with the shallowest likely water input, the fluid source is integrated over a $>1$ year time frame. Furthermore, all sites are depleted relative to the annual average precipitation values, instead centering between March and April precipitation estimates, suggesting reservoir recharge is biased by spring rains and snow melt rather than a fully integrated annual precipitation signal. The lack of strongly enriched isotope values stands in considerable contrast to those from the older deep fluids reported from the South African and Canadian Cratons, where water-rock interaction and hydrothermal alteration drive waters to extreme values (Onstott et al., 2006; Sherwood Lollar et al., 2007) and the ultimate values of fracture fluids reflect mixing between these and paleometeoric fluids.

Murdoch et al. (2011) present a hydrological model for SURF that predicts different water ages in different areas of the mine. On the south side of the mine and within the main workings, even at depths exceeding $5000 \mathrm{ft}$, the putative ages are young, $<10-100$ years. On the north side, away from the main ledge, the ages can be much older, ranging from $<100$ years at shallow depths to $>10,000$ years below $\sim 3000 \mathrm{ft}$. Our water isotope data (Figure 3) appear to reflect these predicted residence times. For instance, D4, D5, and D2 produced similar water isotope patterns and based on Murdoch's model are predicted to be very young fluids with locations on the far south side (D4 and D5) and near the open cut (D2). In contrast, D1, D3, and D6 show relative enrichment reflecting incorporation of older water draining from the surrounding region that has been captured by the hydrological depression of the mine. This is consistent with their locations on the east side (D1 and D6) and far northwest side (D3) of the mine. Longer water residence times facilitate increased water-rock interaction and should be reflected in geochemical fingerprints, particularly at D1, D3, and D6.

Borehole logs and broad geological maps document host geology that, combined with ion composition data, paint a complex picture of fluid flow and water-rock interactions. As noted above, fluids at D1, D2, and D3 are enriched in calcium and magnesium relative to fluids at D4, D5, and D6, which are 


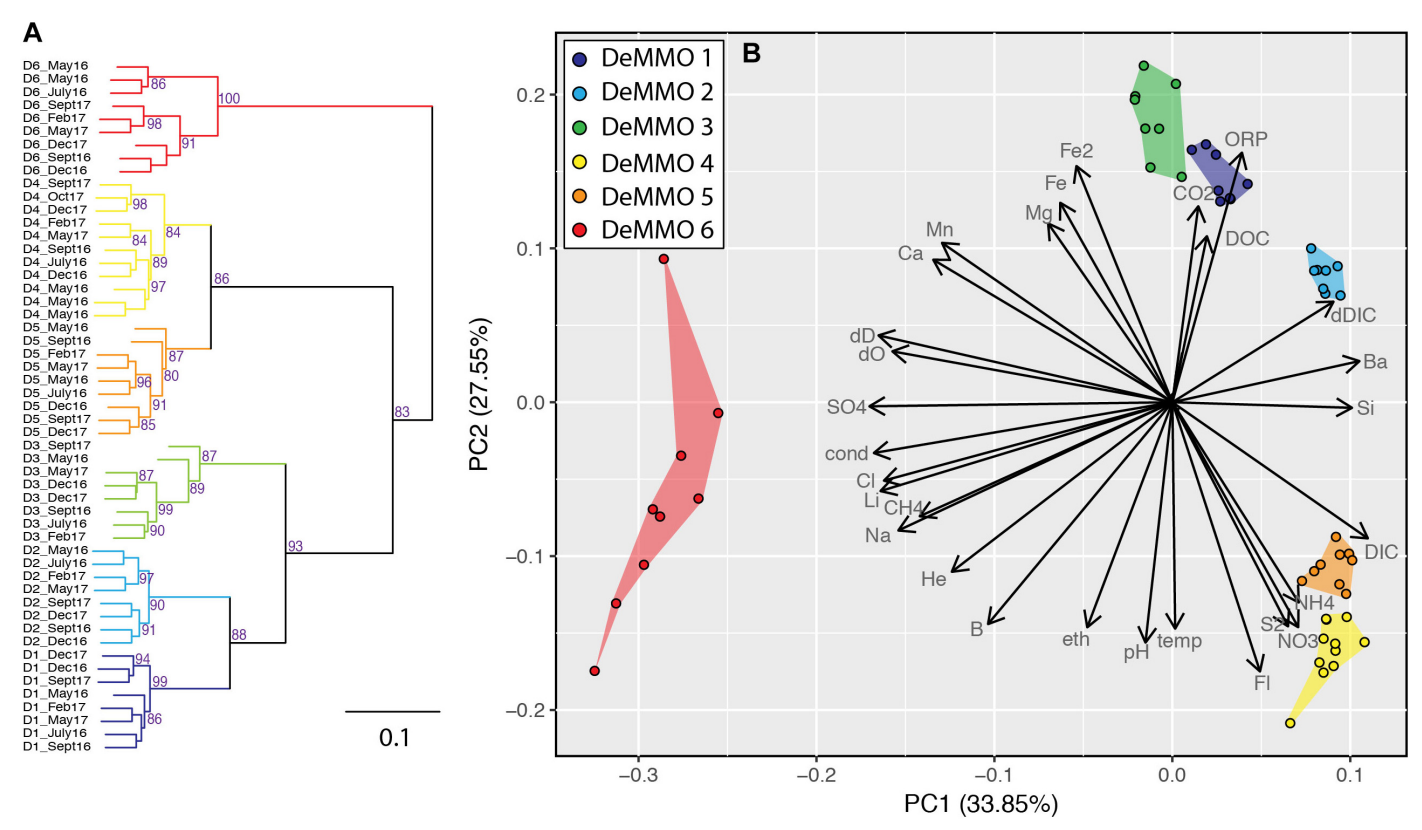

FIGURE 8 | Hierarchical clustering and PCA analysis of sites based on geochemistry inputs. (A) Wards Clustering and Euclidean distance matrix. Bootstrap values $>80$ for higher order nodes shown in purple. (B) Principle components analysis produced in $\mathrm{R}$ with the prcomp() command and visualized using the ggfortify package. Envelopes containing all the points for a given site are highlighted for emphasis. Vectors illustrate the loading of different geochemical parameters on PC1 and PC2.

dominated by $\mathrm{Na}$. The high calcium values in D1 and D2 are consistent with the presence of intermediate to mafic volcanic intrusions, which, as recorded in the drilling logs, are rich in calcium-plagioclase. The source of calcium in D3 is less clear, but perhaps records interactions with rocks beyond those observed in the drill logs. This is also suggested by the high levels of ferrous iron, which cannot be explained by either the presence of a steel packer or volcanic rocks in the borehole trajectory. Particularly curious is the lack of divalent cations in D6. This site is drilled into the Yates Unit, an amphibolite composed of $\sim 80 \%$ hornblende and $20 \%$ intermediate plagioclase, both of which should supply abundant calcium to fluids. Yet, D6 is almost $80 \% \mathrm{Na}$, suggesting that fluids spend much of their long residence time interacting with more sodium-rich rocks. One interpretation is that the D6 source fluid is traveling primarily along tertiary rhyolitic dykes rather than the very massive metabasalt. An additional option is that cation exchange within clay minerals has significantly altered the fluid geochemistry, replacing $\mathrm{Ca}$ and $\mathrm{Mg}$ in shallow fluids with $\mathrm{Na}$ at depth.

It can be seen in Figure $\mathbf{4} \mathbf{B}$ that all of the fluids are sulfate-rich and chloride-poor, but D2, D4, and D5 are best characterized as mixed carbonate-sulfate fluids. The presence and metamorphic grade of the Homestake Formation can account for the bicarbonate. At low metamorphic grade identified at D2, D4, and D5, Homestake Formation contains abundant siderite, a ferrous iron carbonate. At higher grades, as recorded at D3, Homestake Formation instead contains grunerite, an iron silicate. The lack of covariation between calcium and carbonate also supports a siderite origin for the carbonate ion as opposed to sedimentary calcium carbonate cements or veins. Thermodynamic calculations of mineral saturation state reveal that calcite and aragonite are only weakly oversaturated in D2-D6 although dolomite is weakly oversaturated at all sites (see Supplementary Data). Lastly, in addition to relatively high sulfate concentrations, the fluids at D1, D3, and D6 also contain abundant ferrous iron. This combination suggests a similar source, such as the dissolution of iron sulfide minerals or leaching of mafic volcanic rocks.

\section{Statistical Evaluation of Similarity}

Regardless of the specific flow paths and water-rock interactions, the geochemical fingerprints of each DeMMO fluid is distinct. Statistical analysis of variance can be used to evaluate how strongly these fingerprints are supported through time and evaluate the dominant parameters responsible for these groupings. Two visual representations of these relationships are portrayed in Figure 8. Hierarchical clustering of all sites based on variance of all parameters at each time point are illustrated in Figure 8A. The predominantly high bootstrap values indicate a strong level of support of each node. We observe clear clustering of data from each site through time with strong statistical support and no exceptions. D6 is the most divergent, branching away from all other sites at the first node. As predicted from broad geochemical signals, D4 and D5 cluster together, but importantly are separated with high statistical support. The notable differences in dissolved gas concentrations are the only major chemical differences between D4 and D5. This may be explained by temperature and hole geometry as D4 is relatively cool (average $25.3^{\circ} \mathrm{C}$ ) 


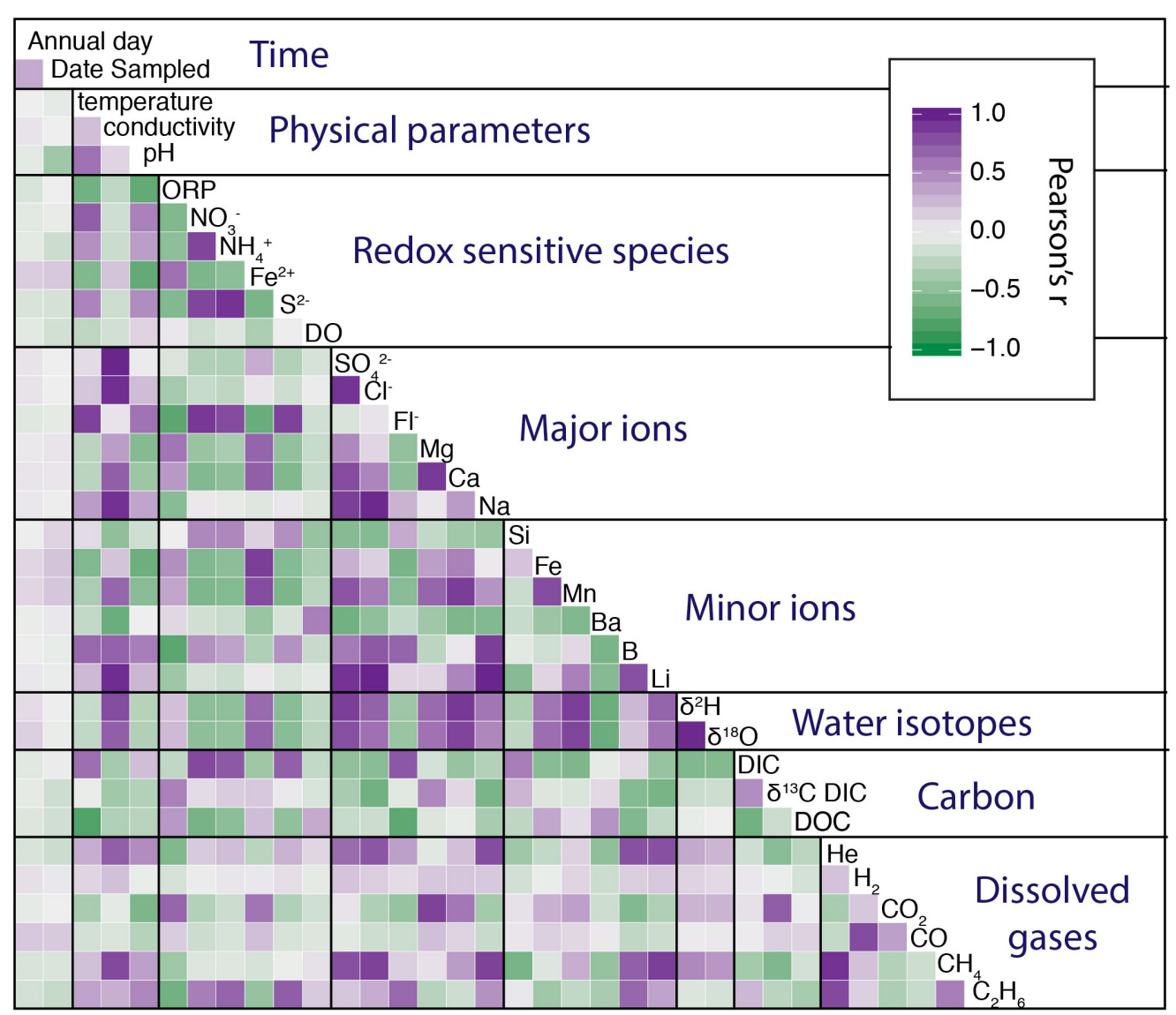

FIGURE 9 | Correlogram of all geochemical data showing Pearson's r correlation between variables with color. Correlogram was generated with GGally r package.

and drilled downward, both of which serve to promote higher dissolved gas concentrations. In contrast, D5 is warm (average $31.7^{\circ} \mathrm{C}$ ) and drilled upward, limiting the storage capacity of dissolved gases. The shallower sites D1, D2, and D3 branch away from the deeper ones in a single node and D1 and D2 branch separately from D3. This clustering strongly supports our conclusion of distinct and stable geochemistry of each DeMMO site through time.

The principal components analysis (PCA) in Figure 8B illustrates the same associations seen in hierarchical clustering analysis, but additionally allows for comparison of how the geochemical parameters themselves plot in the sample ordination, and thus, which parameters are most responsible for separation. Variations in PC1 show positive loading of DIC, $\mathrm{Ba}, \mathrm{Si}, \delta^{13} \mathrm{C}_{\mathrm{DIC}}$, and ammonium and negative loading with sulfate, conductivity, water isotopes, lithium, and $\mathrm{Cl}^{-}$. These parameters effectively separate D6 from all other samples. PC2 shows strong positive loading with ORP, iron, carbon dioxide, DOC and magnesium and negative loading with fluorine, temperature, $\mathrm{pH}$, ethane, and nitrate. Variation in PC2 shows clear separation of D1, D2, and D3 from D4 and D5 based on nutrient concentrations, redox balance, and carbon sources. This plot is also useful for observing that even with variance between points for a given site, each remains distinct from even their closest spatial and geochemical neighbors.

\section{Relationship Between Geochemical Parameters}

In addition to understanding the relationship between sites, it is also useful to compare the relationship between geochemical parameters in this large dataset. To achieve this, we present a correlogram of pairwise correlation coefficients (Figure 9). We see strong positive (purple) and negative (green) correlations between many parameters. Some of these are very intuitive and expected, for instance the correlation between $\delta^{18} \mathrm{O}$ and $\delta^{2} \mathrm{H}$ in water isotopes which could be predicted by the meteoric water line. Another proof of concept is the positive correlation of major ions with both minor ions and conductivity. The correlations between water isotopes, major and minor ions, and conductivity support our identification of discrete water masses, where water isolation time modulates all of these variables. Other relationships are less intuitive and perhaps more informative, such as the lack of correlation between either annual day or date sampled and any geochemical parameter. This supports our conclusion that, as a whole, there are no long-term secular or seasonal trends in the data. An additional notable observation is that temperature 


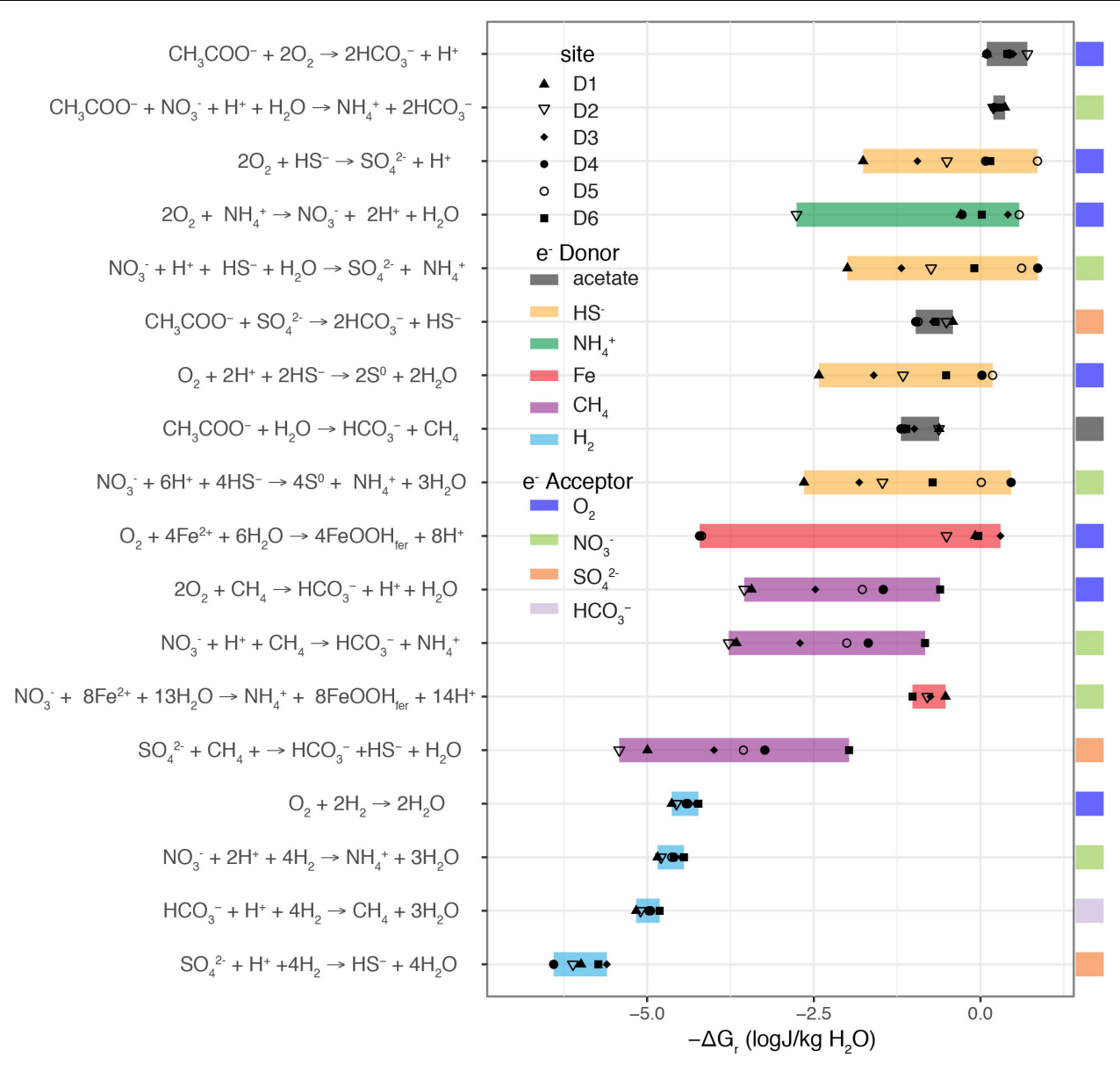

FIGURE 10 | Gibbs energy density of possible metabolic reactions for each DeMMO site. Full reactions are written on the left. Calculations for each site are indicated in by symbols where the full range observed for all sites is highlighted in a color bar corresponding to the e- donor. e- acceptor is indicated in the color bar on the far right.

has a strong negative correlation with DOC $(r=-0.75)$. This relationship is as strong as the correlation between DOC and depth $(r=-0.77)$. We might conclude that temperature is related to isolation age of the fluid and this represents a long-term utilization gradient. However, this is not supported by the relatively young expected age of D5 (based on water isotopes and mine geometry), which is also the warmest. Instead this correlation suggests more rapid utilization of DOC at higher temperatures. Another interesting observation is the relationship between helium, methane, and ethane. While both abiotic and biotic mechanisms of methane production produce ethane (albeit with at different ratios, e.g., Sherwood Lollar et al., 2007), there is no biotic helium production mechanism. This combined with the observed variable methane/ethane ratios, suggest both biotic and abiotic sources of methane in different ratios at different sites.

\section{Trajectories With Time}

Overall, we observe strong temporal consistency and large differences between study sites. This stability was not necessarily expected and has important implications for the use of mines as deep subsurface biosphere sampling points and our conclusions toward this biosphere as a whole. The SURF facility itself is dynamic, with strong seasonal changes in drainage into the mine based on local precipitation events and snow melt. We know that in sampling mine boreholes we are incorporating fluids coming from isolated fractures reflective of the greater deep subsurface and also those percolating through mine workings. It would be reasonable to expect that significant drainage events might impact at least the shallowest sites and/or the proportion of fracture fluid vs. mine-derived fluid in any site. The strong stability in major and minor ions, water isotopes, and physical parameters argues against any change in the fluid source to the DeMMO sites for a 2-year time period. This gives credence to our use of these sites as portals into the deep subsurface and gives a minimum integration timescale of $>1$ year to even the shallowest sites.

Site-specific trends in our data relate primarily to direct physical perturbation of the systems by either drilling borehole outlets or opening and closing of sampling manifolds. Sites D3, D4, and D5 were significantly modified by removal of concrete plugs. This produced large and obvious changes to the flow rates and redox sensitive geochemical measurements. For instance, 
ORP values at 150-225 days, the time during and immediately after modification, varied considerably from values recorded both before and afterward (see Figure 5). Modification also appears to have affected ammonium in D4, which spiked at the perturbation and then returned to the pre-perturbation value after $\sim 1$ year (Figure 5). Perhaps surprisingly, borehole outlet modification does not appear to have affected the conservative ion chemistry of the three drilled sites at all, suggesting the fluid itself emerges much deeper within the borehole. D6 was also significantly altered over the course of this dataset despite limited modification of the manifold itself. At this site, opening the sampling port to allow for the installation of continuous flow experiments in July 2016, changed this from a closed system to an open system. After 6 months of continuous flow, the hole ran dry and was then returned to a closed system state that has subsequently refilled (Figure 1). Remarkably, despite these substantial perturbations, most of the observed chemistry did not significantly change from before to after perturbation. DOC, ferrous iron, dissolved gas concentrations, and ORP do vary through time and may be related to the biogeochemical implications of packering the systems.

\section{Habitability Potential of Each Site}

Each DeMMO site presents a unique window into the deep subsurface with a distinct chemical buffet available to microorganisms. While the microbial ecology of these sites is beyond the scope of this manuscript, the geochemical data described here can be used to calculate redox energetics and posit potential metabolisms. As we observe strong concentration differences in both electron acceptors and electron donors available for microbial metabolisms, we can expect that different sites might be habitable to a different subset of microbes. Here we present values of Gibbs energy of reaction as energy density (J per kg of water) for key microbial metabolisms following the approach of Osburn et al. (2014). We use only species directly measured in this study, testing pairwise reactions of electron acceptors $\mathrm{O}_{2}$, nitrate, sulfate, and $\mathrm{HCO}_{3}{ }^{-}$to oxidize electron donors hydrogen, ferrous iron, ammonium, sulfide, methane, and acetate. Reactions that were exergonic at least at one site are shown in Figure 10. In systems with limited flow (and therefore limited recharge of reactants and removal of products), energy densities are arguably more informative than energies per mole, which assume a constant, and hence unlikely resupply of oxidants and limiting reactants (Osburn et al., 2014).

Using this analysis, we can posit which metabolisms are possible and most profitable at each of the DeMMO sites, informing their habitability. Our calculations indicate that, unlike in most surface environments, oxygen and nitrate utilizing reactions are similarly energy-rich, and nitrate is the most consistently exergonic electron acceptor at D4. Sulfate reduction with hydrogen, methane, or acetate as electron donor are all exergonic, with the highest energy density deriving from acetate oxidation. Both acetoclastic and hydrogenotrophic methanogenesis are energy yielding at all sites. Hydrogenotrophic methanogenesis is the more exergonic on a per mole electrons basis, but due to low hydrogen concentrations, acetoclastic methanogenesis is more exergonic when evaluating energy density. Our results are extremely consistent with those of Osburn et al. (2014) which showed that reactions including sulfide, sulfur, ferrous iron, manganese, and ammonium to be the most exergonic. The previous study, however, didn't not address heterotrophic reactions.

Acetate oxidation yields energy at all six sites, and it is the most exergonic process at D1, D2, D3, and D6. This suggests that significant heterotrophic activity is possible even at great depth in the subsurface. In contrast, at D4 and D5, oxidation of sulfide to either elemental sulfur or to sulfate with either oxygen or nitrate are the most exergonic reactions. Visual evidence of these processes are the luxuriant white, sulfur-bearing microbial mats found at these sites (Figure 11A). Also, Osburn et al. (2014) found numerous putative sulfide oxidizing microbes based on DNA sequencing at $\mathrm{BH} 8$ which is equivalent to D5. Iron oxidation could be an important metabolism at D1, D2, D3, and D6. Again, we see evidence for these metabolisms in the red, iron-rich biofilms formed at the borehole outlets. Visualization of these iron oxides via scanning electron microscopy further reveals that they are composed almost exclusively of the distinctive twisted stalks (Figure 11B) produced by direct microbial iron oxidation by Gallionella-like species (Emerson and Moyer, 1997). Osburn et al. (2014) identified putative iron

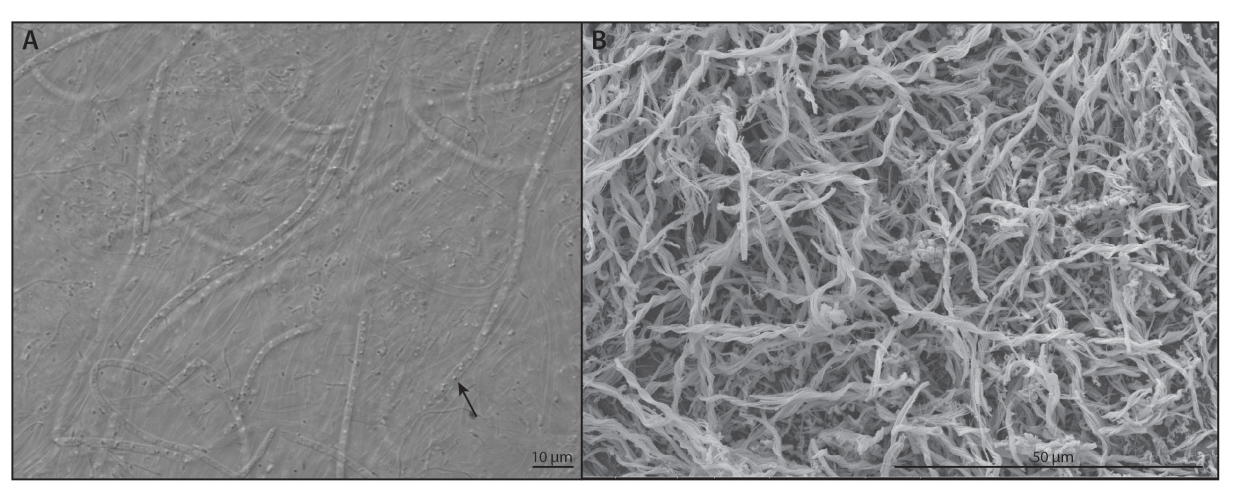

FIGURE 11 | Microscopic images indicating microbial metabolisms. (A) light microscopy image of a putative sulfide oxidizing filamentous bacterium with intracellular $S^{0}$ globules (arrow) taken from the outflow of D5 (B) SEM image of a twisted iron oxide stalk from the outflow of D3 produced by putative iron oxidizing bacteria. 
oxidizers in $\mathrm{BH} 2$ (D1), BH5 (D2) although not Manifold B (D6). Ammonium oxidation is a viable metabolism at all sites but D2, where it is exergonic but has very low energy density. Methanogenesis generally has low energy density, but is viable at D6 and to a lesser degree at D4 and D5. Interestingly, these calculations correspond quite well to where and in what concentrations we observe methane (see Figure 6) although methanogens were found only in very low abundance by Osburn et al. (2014). In summary, the close agreement between our calculations and tangible observations yields confidence in this approach to defining habitability. We find that there is a rich assortment of both lithotrophic and heterotrophic metabolisms are possible at each site, although these vary considerably between sites, creating a distinct habitability fingerprint for each of these windows into the deep subsurface.

\section{CONCLUSION}

The now-established Deep Mine Microbial Observatory (DeMMO) is a new portal into the deep subsurface biosphere. The two-year time series presented here establishes baseline geochemical conditions of each site, identifies variability, and characterizes inherent controls on habitability. We observe distinct yet remarkably stable geochemical profiles at each site, suggesting a separate water source for each. Water isotopes and conductivity measurements support the presence of relatively young fluids at D2, D4, and D5 compared to relatively older fluids at D1, D3, and D6. Cationic compositions do not always correspond in a straightforward way to the lithologies encountered in each borehole log. We suggest that this may indicate longer than predicted fluid flow paths, channelized flow within intrusive rocks or quartz veins, and/or clay exchange. Using this timeseries, we are able to observe the changes induced by outlet modification of historical boreholes. Redox sensitive ions were the most sensitive to these anthropogenic perturbations and stabilized after $\sim<1$ year, whereas major ions were largely insensitive to these changes. We suggest this might inform future efforts within the community to modify and sample other deep subsurface sites. Energetic calculations identify a number of profitable sources of energy available to subsurface inhabitants of the DeMMO network, particularly sulfide and iron oxidation as well as heterotrophic reactions. We hope that this baseline serves to introduce the community to DeMMO

\section{REFERENCES}

Alter, M. D., and Steiof, M. (2005). Optimized method for dissolved hydrogen sampling in groundwater. J. Contam. Hydrol. 78, 71-86. doi: 10.1016/j.jconhyd. 2005.03.002

Amend, J. P., and Teske, A. (2005). Expanding frontiers in deep subsurface microbiology. Palaeogeogr. Palaeoclimatol. Palaeoecol. 219, 131-155. doi: 10. 1016/j.palaeo.2004.10.018

Bowen, G. (2018). The Online Isotopes in Precipitation Calculator, version 3.1.

Bowen, G. J., and Revenaugh, J. (2003). Interpolating the isotopic composition of modern meteoric precipitation. Water Resour. Res. 39:1299. doi: 10.1029/ 2003WR002086 such that it may be a resource for future queries into the deep subsurface environment.

\section{DATA AVAILABILITY}

All datasets generated for this study are included in the manuscript and/or the Supplementary Files.

\section{AUTHOR CONTRIBUTIONS}

MO designed the study and wrote the manuscript. BK was the field manager of the project and directed each field expedition. CC was a graduate student working at the site who collected most of the samples and performed microscopy. AM was our isotope lab manager who produced DIC concentration and isotope data. JA was PI of NAI Life Underground which funded most of this work. All authors contributed to the creation of the manuscript and study design.

\section{FUNDING}

This work was funded with NAI grant \#NNAI3AA92A to JA (PI) and MO (Co-I) and NASA Exobiology grant \#NNX15AM086 to MO.

\section{ACKNOWLEDGMENTS}

Many people contributed to the successful completion of this project. We thank Pratixaben Savalia for producing dissolved gas measurements and George Rose for machining the packer components. In addition, we thank Jaret Heise, Tom Reagan, and Kathy Hart from SURF for their assistance with field expeditions, access to maps and drill logs, and for permission to publish Figure 2.

\section{SUPPLEMENTARY MATERIAL}

The Supplementary Material for this article can be found online at: https://www.frontiersin.org/articles/10.3389/feart. 2019.00196/full\#supplementary-material

Bowen, G. J., Wassenaar, L. I., and Hobson, K. A. (2005). Global application of stable hydrogen and oxygen isotopes to wildlife forensics. Oecologia 143, 337-348. doi: 10.1007/s00442-004-1813-y

Caddey, S. W. (1991). The Homestake Gold Mine, an Early Proterozoic ironformation-hosted gold deposit, Lawrence County, South Dakota. Reston, VA: U.S. Geological Survey.

Cardace, D., Hoehler, T., McCollom, T., and Schrenk, M. (2013). Establishment of the coast range ophiolite microbial observatory (CROMO): drilling objectives and preliminary outcomes. Sci. Drill. 16, 45-55. doi: 10.5194/sd-16-452013

Cavicchioli, R. (2002). Extremophiles and the search for extraterrestrial life. Astrobiology 2, 281-292. doi: 10.1089/153110702762027862 
Chapelle, F. H., O’neill, K., Bradley, P. M., Methé, B. A., Ciufo, S. A., Knobel, L. L., et al. (2002). A hydrogen-based subsurface microbial community dominated by methanogens. Nature 415, 312-315. doi: 10.1038/415312a

Chivian, D., Brodie, E. L., Alm, E. J., Culley, D. E., Dehal, P. S., DeSantis, T. Z., et al. (2008). Environmental genomics reveals a single-species ecosystem deep within Earth. Science 322, 275-278. doi: 10.1126/science.1155495

Colman, D. R., Poudel, S., Stamps, B. W., Boyd, E. S., and Spear, J. R. (2017). The deep, hot biosphere: twenty-five years of retrospection. PNAS 114, 6895-6903. doi: $10.1073 /$ pnas.1701266114

Colwell, F. S., and D'Hondt, S. (2013). Nature and extent of the deep biosphere. Rev. Mineral. Geochem. 75, 547-574. doi: 10.2138/rmg.2013.75.17

Colwell, F. S., and Lehman, R. M. (1997). Carbon source utilization profiles for microbial communities from hydrologically distinct zones in a basalt aquifer. Microb. Ecol. 33, 240-251. doi: 10.1007/s002489900027

Criss, R. E. (1999). Principles of Stable Isotope Distribution. Oxford: Oxford University Press.

Emerson, D., and Moyer, C. (1997). Isolation and characterization of novel ironoxidizing bacteria that grow at circumneutral pH. Appl. Environ. Microbiol. 63, 4784-4792.

Flynn, T. M., Sanford, R. A., and Bethke, C. M. (2008). Attached and suspended microbial communities in a pristine confined aquifer. Water Resour. Res. 44, 832-837. doi: 10.1029/2007WR006633

Fredrickson, J. K., and Onstott, T. C. (2001). "Biogeochemical and geological significance of subsurface microbiology," in Subsurface Microbiology and Biogeochemistry, ed. J. K. Fredrickson (Hoboken, NJ: Wiley-Liss), 3-37.

Fry, J. C., Horsfield, B., Sykes, R., Cragg, B. A., Heywood, C., Kim, G. T., et al. (2009). Prokaryotic populations and activities in an interbedded coal deposit, including a previously deeply buried section (1.6-2.3 km) Above $150 \mathrm{Ma}$ basement rock. Geomicrobiol. J. 26, 163-178. doi: 10.1080/01490450902724832

Gat, J. R. (1996). Oxygen and hydrogen isotopes in the hydrologic cycle. Annu. Rev. Earth Planet. Sci. 24, 225-262. doi: 10.1146/annurev.earth.24.1.225

Griebler, C., and Lueders, T. (2009). Microbial biodiversity in groundwater ecosystems. Freshw. Biol. 54, 649-677. doi: 10.1111/j.1365-2427.2008.02013.x

Heise, J. (2015). The sanford underground research facility at homestake. J. Phys. Conf. Ser. 606, 12015-12026. doi: 10.1088/1742-6596/606/1/012015

Holland, G., Lollar, B. S., Li, L., Lacrampe-Couloume, G., Slater, G. F., and Ballentine, C. J. (2013). Deep fracture fluids isolated in the crust since the Precambrian era. Nature 497, 357-360. doi: 10.1038/nature12127

Kennedy, J. R., Koth, K. R., and Carruth, R. (2015). Surface and Subsurface Microgravity Data in the Vicinity of Sanford Underground Research Facility, Lead, South Dakota. U.S. Geological Survey: Reston, VA

Kietavainen, R., Ahonen, L., Niinikoski, P., Nykänen, H., and Kukkonen, I. T. (2017). Abiotic and biotic controls on methane formation down to $2.5 \mathrm{~km}$ depth within the Precambrian Fennoscandian Shield. Geochim. Cosmochim. Acta 202, 124-145. doi: 10.1016/j.gca.2016.12.020

Küsel, K., Totsche, K. U., Trumbore, S. E., Lehmann, R., Steinhäuser, C., and Herrmann, M. (2016). How deep can surface signals be traced in the critical zone? merging biodiversity with biogeochemistry research in a Central German Muschelkalk Landscape. Front. Earth Sci. 4:32. doi: 10.3389/feart.2016.00032

Leenheer, J. A., Malcolm, R. L., and McKinley, P. W. (1974). Occurrence of dissolved organic carbon in selected ground-water samples in the united states. J. Res. U.S. Geol. 2, 361-369.

Li, L., Wing, B. A., Bui, T. H., McDermott, J. M., Slater, G. F., Wei, S., et al. (2016). Sulfur mass-independent fractionation in subsurface fracture waters indicates a long-standing sulfur cycle in Precambrian rocks. Nat. Commun. 516, 1-9. doi: $10.1038 /$ ncomms 13252

Magnabosco, C., Ryan, K., Lau, M. C. Y., Kuloyo, O., Lollar, B. S., Kieft, T. L., et al. (2015). A metagenomic window into carbon metabolism at $3 \mathrm{~km}$ depth in Precambrian continental crust. Nat. Publish. Group 10, 730-741. doi: 10.1038/ ismej.2015.150

Magot, M., Ollivier, B., and Patel, B. (2000). Microbiology of petroleum reservoirs. Antonie Van Leeuwenhoek 77, 103-116.

Mitchell, S. T. (2009). Nuggets to Neutrinos: The Homestake Story. Bloomington, IN: Xlibris Corporation.

Momper, L., Jungbluth, S. P., Lee, M. D., and Amend, J. P. (2017a). Energy and carbon metabolisms in a deep terrestrial subsurface fluid microbial community. ISME J. 11, 2319-2333. doi: 10.1038/ismej.2017.94
Momper, L., Kiel Reese, B., Zinke, L., Wanger, G., Osburn, M. R., Moser, D., et al. (2017b). Major phylum-level differences between porefluid and host rock bacterial communities in the terrestrial deep subsurface. Environ. Microbiol. Rep. 9, 501-511. doi: 10.1111/1758-2229.12563

Morelli, R. M., Bell, C. C., Creaser, R. A., and Simonetti, A. (2010). Constraints on the genesis of gold mineralization at the Homestake Gold Deposit, Black Hills, South Dakota from rhenium-osmium sulfide geochronology. Miner. Deposita 45, 461-480. doi: 10.1007/s00126-010-0284-9

Murdoch, L. C., Germanovich, L. N., Wang, H., Onstott, T. C., Elsworth, D., Stetler, L., et al. (2011). Hydrogeology of the vicinity of Homestake mine, South Dakota, USA. Hydrogeol. J. 20, 27-43. doi: 10.1007/s10040-0110773-7

Murphy, E. M., Schramke, J. A., Fredrickson, J. K., Bledsoe, H. W., Francis, A. J., Sklarew, D. S., et al. (1992). The influence of microbial activity and sedimentary organic carbon on the isotope geochemistry of the middendoff aquifer. Water Resour. Res. 28, 723-740. doi: 10.1029/91wr02678

Nealson, K., Inagaki, F., and Takai, K. (2005). Hydrogen-driven subsurface lithoautotrophic microbial ecosystems (SLiMEs): do they exist and why should we care? Trends Microbiol. 13, 405-410. doi: 10.1016/j.tim.2005.07.010

Nyyssonen, M., Hultman, J., Ahonen, L., Kukkonen, I., Paulin, L., Laine, P., et al. (2013). Taxonomically and functionally diverse microbial communities in deep crystalline rocks of the Fennoscandian shield. ISME J. 8, 126-138. doi: 10.1038/ ismej.2013.125

Onstott, T. C., Lin, L. H., Davidson, M., Mislowack, B., Borcsik, M., Hall, J., et al. (2006). The origin and age of biogeochemical trends in deep fracture water of the Witwatersrand Basin, South Africa. Geomicrobiol. J. 23, 369-414. doi: 10.1080/01490450600875688

Osburn, M. R., LaRowe, D. E., Momper, L. M., and Amend, J. P. (2014). Chemolithotrophy in the continental deep subsurface: Sanford underground research facility (SURF), USA. Front. Microbiol. 5:610. doi: 10.3389/fmicb.2014. 00610

Pedersen, K. (1996). 16S rRNA gene diversity of attached and unattached bacteria in boreholes along the access tunnel to the Äspö hard rock laboratory, Sweden. FEMS Microbiol. Ecol. 19, 249-262. doi: 10.1016/0168-6496(96)00017-7

Pedersen, K. (2001). "Diversity and activity of microorganisms in deep igneous rock aquifers of the Fennoscandian Shield," in Subsurface Microbiology and Biogeochemistry, eds J. K. Fredrickson and M. Fletcher (Hoboken, NJ: WileyLiss), 97-139.

Pedersen, K., Bomberg, M., and Itävaara, M. (2014). Summary Report Microbiology of Olkiluoto and ONKALO Groundwater. Report number: Posiva report 2012-42. Eurajoki: Posiva Oy.

Probst, A. J., Castelle, C. J., Singh, A., Brown, C. T., Anantharaman, K., Sharon, I., et al. (2016). Genomic resolution of a cold subsurface aquifer community provides metabolic insights for novel microbes adapted to high CO2 concentrations. Environ. Microbiol. 19, 459-474. doi: 10.1111/1462-2920. 13362

Probst, A. J., Ladd, B., Jarett, J. K., Geller-McGrath, D. E., Sieber, C. M. K., Emerson, J. B., et al. (2018). Differential depth distribution of microbial function and putative symbionts through sediment-hosted aquifers in the deep terrestrial subsurface. Nat. Microbiol. 3, 328-336. doi: 10.1038/s41564-017-0098-y

Purkamo, L., Bomberg, M., Kietäväinen, R., Salavirta, H., Nyyssönen, M., Nuppunen-Puputti, M., et al. (2016). Microbial co-occurrence patterns in deep Precambrian bedrock fracture fluids. Biogeosciences 13, 3091-3108. doi: 10. 5194/bg-13-3091-2016

Rastogi, G., Gurram, R. N., Bhalla, A., Gonzalez, R., Bischoff, K. M., Hughes, S. R., et al. (2013). Presence of glucose, xylose, and glycerol fermenting bacteria in the deep biosphere of the former Homestake gold mine, South Dakota. Front. Microbiol. 4:18. doi: 10.3389/fmicb.2013.00018

Rastogi, G., Osman, S., Kukkadapu, R., Engelhard, M., Vaishampayan, P. A., Andersen, G. L., et al. (2010). Microbial and mineralogical characterizations of soils collected from the deep biosphere of the Former Homestake Gold Mine, South Dakota. Microb. Ecol. 60, 539-550. doi: 10.1007/s00248-0109657-y

Rastogi, G., Stetler, L. D., Peyton, B. M., and Sani, R. K. (2009). Molecular analysis of prokaryotic diversity in the deep subsurface of the former Homestake gold mine, South Dakota, USA. J Microbiol. 47, 371-384. doi: 10.1007/s12275-0080249-1 
Sherwood Lollar, B., Voglesonger, K., Lin, L. H., Lacrampe-Couloume, G., Telling, J., Abrajano, T. A., et al. (2007). Hydrogeologic controls on episodic $\mathrm{H}_{2}$ release from precambrian fractured rocks-energy for deep subsurface life on earth and mars. Astrobiology 7, 971-986. doi: 10.1089/ast.2006.0096

Simkus, D. N., Slater, G. F., Lollar, B. S., Wilkie, K., Kieft, T. L., Magnabosco, C., et al. (2016). Variations in microbial carbon sources and cycling in the deep continental subsurface. Geochim. Cosmochim. Acta 173, 264-283. doi: 10.1016/ j.gca.2015.10.003

Steadman, J. A., and Large, R. R. (2016). Synsedimentary, diagenetic, and metamorphic pyrite, pyrrhotite, and marcasite at the homestake BIF-Hosted Gold Deposit, South Dakota, USA: insights on Au-As ore genesis from textural and LA-ICP-MS trace element studies. Econ. Geol. 111, 1731-1752. doi: 10. 2113/econgeo.111.7.1731

Stevens, T. O., and McKinley, J. P. (1995). Lithoautotrophic microbia, ecosystems in deep basalt aquifers. Science 270, 450-454. doi: 10.1126/science.270. 5235.450

Stroes-Gascoyne, S., Schippers, A., Schwyn, B., Poulain, S., Sergeant, C., Simonoff, M., et al. (2007). Microbial community analysis of opalinus clay drill core samples from the mont terri underground research laboratory, Switzerland. Geomicrobiol. J. 24, 1-17. doi: 10.1080/01490450601134275

Vető, I., Futó, I., Horváth, I., and Szántó, Z. (2004). Late and deep fermentative methanogenesis as reflected in the $\mathrm{H}-\mathrm{C}-\mathrm{O}-\mathrm{S}$ isotopy of the methane-water system in deep aquifers of the Pannonian Basin (SE Hungary). Organ. Geochem. 35, 713-723. doi: 10.1016/j.orggeochem.2004.02.004

Waddell, E. J., Elliott, T. J., Vahrenkamp, J. M., Roggenthen, W. M., Sani, R. K., Anderson, C. M., et al. (2010). Phylogenetic evidence of noteworthy microflora from the subsurface of the former Homestake gold mine, Lead, South Dakota. Environ. Technol. 31, 979-991. doi: 10.1080/09593331003789511

Welker, J. M. (2000). Isotopic (d18O) characteristics of weekly precipitation collected across the USA: an initial analysis with application to water source studies. Hydrol. Process. 14, 1449-1464. doi: 10.1002/1099-1085(20000615)14: 8<1449::aid-hyp993<3.0.co;2-7

Conflict of Interest Statement: The authors declare that the research was conducted in the absence of any commercial or financial relationships that could be construed as a potential conflict of interest.

Copyright (0) 2019 Osburn, Kruger, Masterson, Casar and Amend. This is an openaccess article distributed under the terms of the Creative Commons Attribution License (CC BY). The use, distribution or reproduction in other forums is permitted, provided the original author(s) and the copyright owner(s) are credited and that the original publication in this journal is cited, in accordance with accepted academic practice. No use, distribution or reproduction is permitted which does not comply with these terms. 